\title{
Outburst flood scenarios and risks for a rapidly growing high- mountain city: Pokhara, Nepal
}

Melanie Fischer ${ }^{1}$, Jana Brettin $^{1}$, Sigrid Roessner ${ }^{2}$, Ariane Walz ${ }^{1}$, Monique Fort ${ }^{3}$, Oliver Korup ${ }^{1,4}$

${ }^{1}$ Institute of Environmental Science and Geography, University of Potsdam, Potsdam, Germany

$5 \quad{ }^{2}$ Helmholtz Centre Potsdam, GFZ German Research Centre for Geosciences, Potsdam, Germany

${ }^{3}$ Département de Géographie, Université Paris-Cité, Paris, France

${ }^{4}$ Institute of Geosciences, University of Potsdam, Potsdam, Germany

Correspondence to: Melanie Fischer melaniefischer@uni-potsdam.de 


\section{Abstract}

Pokhara (c. 850 m a.s.1.), Nepal's second largest city, lies at the foot of the Higher Himalayas and has more than tripled its population in the past three decades. Rapidly expanding built-up areas are high in demand for construction materials and several informal settlements cater to unregulated sand and gravel mining in the Pokhara valley's main river, the Seti Khola. This river is fed by the Sabche glacier below Annapurna III (7,555 m a.s.1.), some $35 \mathrm{~km}$ upstream of the city, and traverses

15 one of the steepest topographic gradients in the Himalayas. In May 2012 an outburst flood caused $>70$ fatalities and intense damage along this river and rekindled concerns about flood-risk management. We estimate the flow dynamics and inundation depths of outburst flood scenarios using the hydrodynamic model HEC-RAS. We simulate the potential impacts of peak discharges from 1,000 to $10,000 \mathrm{~m}^{3} \mathrm{~s}^{-1}$ on land cover based on high-resolution Maxar satellite imagery and OpenStreetMap data (buildings and road network). We also trace the dynamics of two informal settlements near Kaseri and Yamdi with high potential flood impact from RapidEye, PlanetScope, and Google Earth imagery of the past two decades. Our hydrodynamic simulations highlight several sites of potential hydraulic ponding that would largely affect these informal settlements and sites of sand and gravel mining. These built-up areas grew between three and twentyfold, thus likely raising local flood risk well beyond changes in outburst hazard. Besides these drastic local changes, about $1 \%$ of Pokhara's urban built-up area and essential rural road network is in the highest hazard zones highlighted by our outburst simulations. Our results stress the need to adapt early-warning strategies for locally differing hydrological and geomorphic conditions in this rapidly growing urban watershed.

\section{Introduction}

Many mountain communities and their infrastructure have become exposed and vulnerable to natural hazards (Fort, 2015; Hock et al., 2019). The Hindu-Kush Himalayas, home to some 200 million people and "water tower" to 1.3 billion people living downstream (Immerzeel et al., 2010; Schild, 2008), have seen rapid population growth, expanding road networks, shifts from agriculture to tourism as the main economic revenue, and the rise of hydropower projects (Hock et al., 2019; Schwanghart et al., 2018; Sidle and Ziegler, 2012). The Pokhara valley in Nepal, home to the nation's second largest city, is a prime example of such rapid socio-economic development: emerging job opportunities in the tourism sector triggered the steep rise of Pokhara's population since the 1970s, fuelled by unabated migration from rural to urban areas (Rimal et al., 2015, 2018). Urbanisation pressure has also forced informal settlements of marginalised communities on the lowermost river terraces and floodplains of the valley's main river, the Seti Khola (Fort et al., 2018; Thapa et al., 2022).

Apart from annual monsoonal floods, this river has a history of rare outburst floods. On May 5, 2012, a hyperconcentrated flood killed 72 persons and destroyed roads, bridges, and drinking water pipelines in the northern Pokhara valley (Gurung et al., 2015, 2021). The exact sequence of events remains debated, but is likely to have been initiated by rock-slope failures on the western flank of the Annapurna IV massif at 7,525m a. s. 1., observed by chance by a pilot (Hanisch et al., 2013; Kargel et al., 2013). Half an hour later, a sudden flood wave reached Kharapani village (1,100 m a.s.1.), some $23 \mathrm{~km}$ downstream, causing most of the damage and fatalities at an estimated peak discharge of $8,400 \mathrm{~m}^{3} \mathrm{~s}^{-1}$ (Hanisch et al., 2013; Oi et al., 2014; SANDRP, 
2014). Thanks to the pilot, a radio warning was issued, most likely preventing a higher death toll further downstream (Kargel et al., 2013).

Even larger outburst floods may have occurred in the Seti Khola in Medieval times (Fort, 1987; Schwanghart et al., 2016). Yet appraisals of flood hazard have so far largely focused on the 100-year meteorological flood as estimated from rainfall data (Basnet and Acharya, 2019; Gurung et al., 2021). The associated risk estimates rely on land use and land cover (LULC) mapping and projections from Landsat data (Gurung et al., 2021; Rimal et al., 2015, 2018), floodplain mapping (Rimal et al., 2015, 2018), and hydrodynamic modelling for selected reaches (Basnet and Acharya, 2019; Gurung et al., 2021).

We aim to expand on these studies by providing a comprehensive, semi-quantitative estimation of potential outburst flood impacts for the city of Pokhara and surrounding regions. In our approach we recognise possibly inundated areas for different outburst flood scenarios, the types of land cover and infrastructure most likely affected and the role of rapid urban expansion. We intersect the results of hydrodynamic modelling with land cover data on buildings and the road network, and highlight the rapid recent growth of two informal settlements. Our appraisal forms a building block for a more formal risk assessment that is currently curtailed by a lack of data on outburst flood probabilities as well as exposed values. Nonetheless, our study is one of the few to combine outburst flood scenarios with land-cover and land-use changes and might aid both urban planning and anticipatory risk management in the Pokhara valley (Nussbaumer et al., 2014).

\section{Study area}

Pokhara is the second largest city of Nepal, capital of the Kaski District and the Gandaki Province, and lies at the southern foot of the 8-km high, seismically active Annapurna massif of the Higher Himalaya (Fort, 2010; Grandin et al., 2012). The

60 Seti Khola is Pokhara's main river and traverses one of the steepest topographic gradients in the Himalayas, originating at 3,700 m a.s.l. in the Sabche Cirque of the Annapurna massif and entering the city $850 \mathrm{~m}$ a.s.l. some $35 \mathrm{~km}$ downstream (Fig. 1). The headwaters are mainly fed by Sabche glacier, the only glacier with observed surges in the central Himalayas (Lovell et al., 2018). The Seti Khola is also fed by the Mardi Khola, entering the valley in the north-west, and the Phusre Khola, to the south-east of Pokhara.

65 Pokhara is built on a large $\left(>120 \mathrm{~km}^{2}\right)$ intramontane alluvial fan of the Seti Khola. The youngest of three depositional units of this fan is the $60-100 \mathrm{~m}$ thick Pokhara Formation that was formed by (post-)seismic sediment pulses in the $12^{\text {th }}$ to $14^{\text {th }}$ century CE (Fort, 2010; Schwanghart et al., 2016). These mostly unconsolidated gravel beds cap the more indurated, but undated, Ghachok Formation (Fort, 2010). Over a course of $70 \mathrm{~km}$, the Seti Khola cuts through its own sediments, forming broad, unpaired, and 100-m high terraces (Fort, 2010; Stolle et al., 2017). These cut-and-fill terraces alternate with several short $(<1$ $\mathrm{km})$, narrow $(<10 \mathrm{~m}$ ) but up to 90 -m deep gorges, in resistant calcareous rocks of the Ghachok Formation and the bedrock of the Lower Himalayan Sequence (Stolle et al., 2019). Some of these gorges are connected to karst features like potholes, tunnels, and caves (Fort, 2010). 
https://doi.org/10.5194/nhess-2022-64

Preprint. Discussion started: 3 March 2022

(c) Author(s) 2022. CC BY 4.0 License.

(c) (i)

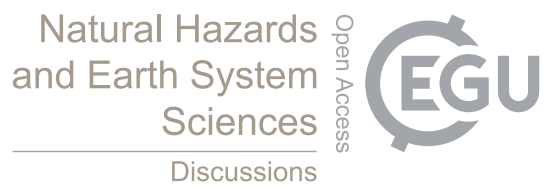

Climate in the Seti Khola catchment is distinctly seasonal. The summer monsoon (May to October) brings $>80 \%$ of the annual precipitation of about $4000 \mathrm{~mm}$ per year (Gabet et al., 2004). Climate also strongly varies with topographic relief (Rimal et

75 al., 2018): the central Pokhara valley has a humid sub-tropical to humid temperate climate with mean monthly temperatures of $13^{\circ} \mathrm{C}$ to $26^{\circ} \mathrm{C}$ (Ross and Gilbert, 1999), whereas temperate to alpine climate characterises the Annapurna massif to the north (Rimal et al., 2015, 2018).

With a population of 518,452 in 2021 (Central Bureau of Statistics, 2022) the city and its surrounding valley have seen rapid socio-economical changes following the construction of major transportation infrastructure since the 1970s, driven by better access to higher standards of living, and inbound migration attracted by the growing tourism sector and new employment opportunities (Fort et al., 2018).

Between 1990 and 2013, the urban area increased by $30 \mathrm{~km}^{2}$, or $2.6 \%$ of the total watershed, whereas cultivated land decreased by $2.5 \%$ (Rimal et al., 2015). Population migration dynamics are also reflected by an increase of $45 \%$ in areas classified as urban in 2010 when compared to Pokhara's municipal area in 1977 (Rimal, 2012; Rimal et al., 2015). The urban population

85 more than tripled since the 1990s (Rimal et al., 2015; United Nations Department of Economic and Social Affairs, 2019). Many informal settlements formed on the lowermost river terraces or the floodplain of the Seti Khola (Fig. 1), where squatters largely rely on gravel and sand mining as an income source (Fort et al., 2018; Stolle, 2018). 


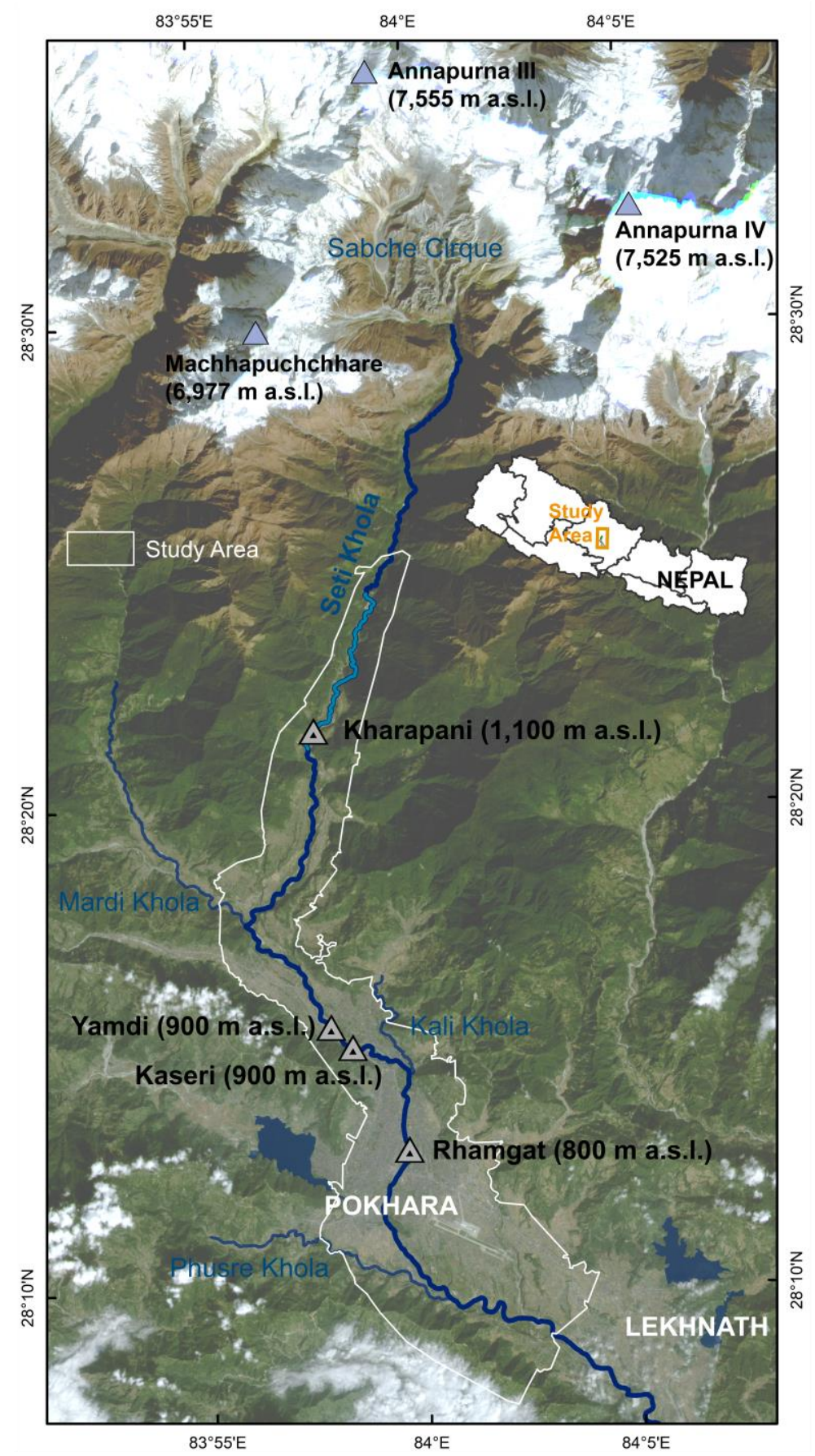

Figure 1: The Pokhara valley and the Seti Khola river in November 2021. Our HEC-RAS model domain and manual land cover mapping covers the study area (white polygon). Most intense damages during the May 2012 outburst flood occurred along the uppermost inhabited reach of the Seti Khola (light blue). Image: PlanetScope (Planet Team, 2017); Nepal administrative boundaries are from UN Office for the Coordination of Humanitarian Affairs - Field Information Services Section (OCHA FISS, 2020) 
https://doi.org/10.5194/nhess-2022-64

Preprint. Discussion started: 3 March 2022

(c) Author(s) 2022. CC BY 4.0 License.

\section{Data and methods}

\section{$95 \quad 3.1$ Overall approach}

We analyse potential flood impacts from physically plausible magnitudes of outburst floods along a 40-km long reach of the Seti Khola. Our assessment is built on combining scenario-based inundation modelling with current land use and land cover (LULC) and data of buildings and the road network to identify areas of potential flood impact (Fig. 2). We also selected two informal settlements close to the river and estimate how the growth of their built-up area between 2008 and 2021 affected their exposure to outburst floods. Stream-gauge data is unavailable for the Seti Khola, hence we validated our model with mapped damage and sediment traces caused by the May 2012 flood.

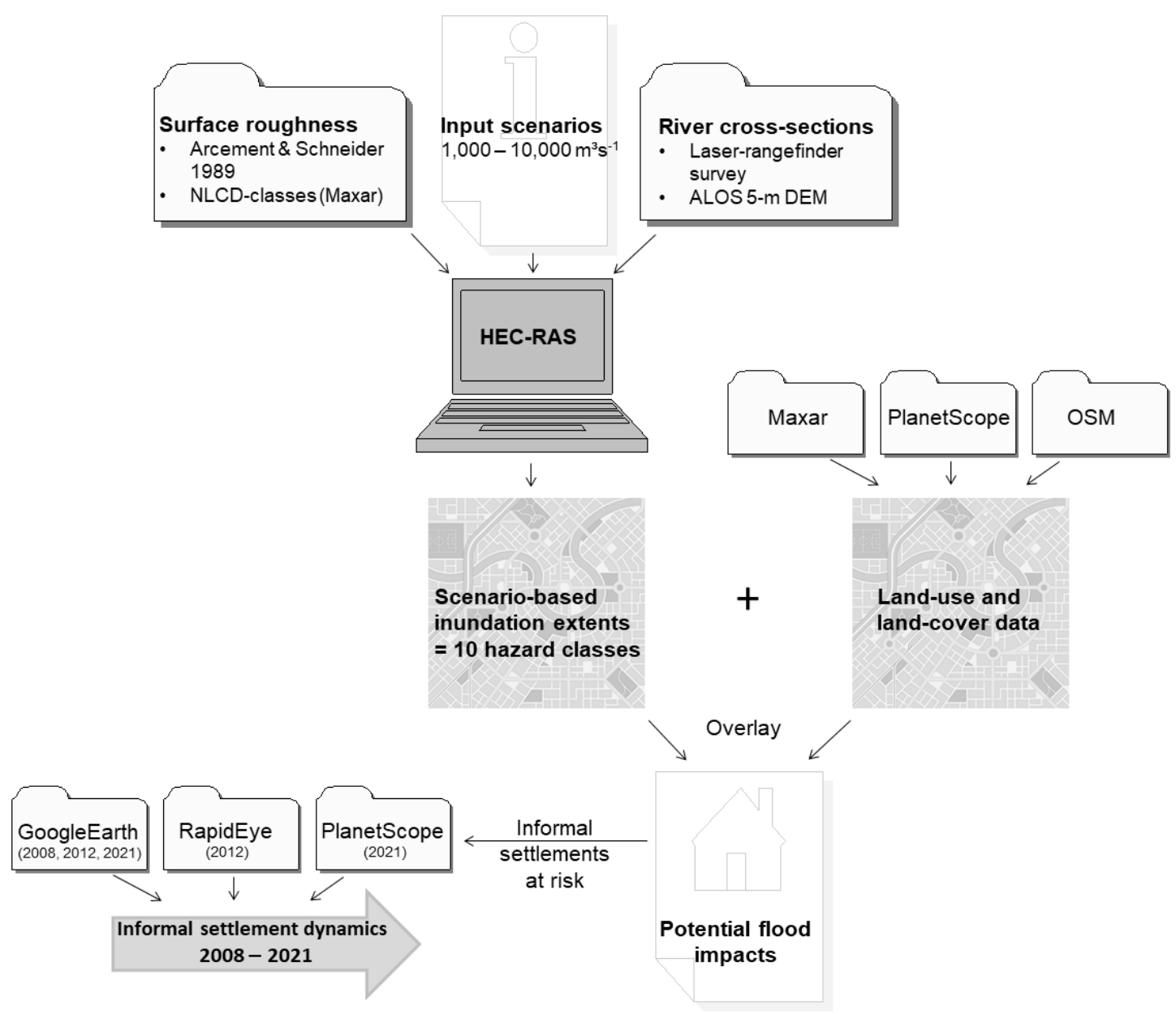

Figure 2: Data sources and workflow of our semi-quantitative assessment of outburst flood impacts in the Pokhara valley. 


\subsection{Scenarios for numerical flood routing}

We simulated ten flood scenarios with the Hydrologic Engineering Center's River Analysis System, HEC-RAS (version 5.0.7; https://www.hec.usace.army.mil/software/hec-ras/). HEC-RAS uses a step method for simulating steady, i.e. constant but gradually varied, open-channel flow in one dimension - based on the Saint-Venant equations (Brunner, 2020a; Westoby et al., 2014). The standard step method computes water-level profiles between two river cross-sections that describe the geometry of the channel and the adjacent overbank areas by iteratively solving the Energy equation (Eq. 1):

$Z_{2}+Y_{2}+\frac{a_{2} V_{2}^{2}}{2 g}=Z_{1}+Y_{1}+\frac{a_{1} V_{1}^{2}}{2 g}+h_{e}$

For cross-sections 1 and 2, $Z_{1}$ and $Z_{2}$ describe their main channel bed elevations, $Y_{1}$ and $Y_{2}$ the corresponding flow depths, $V_{1}$ and $V_{2}$ the mean flow velocities, and $a_{1}$ and $a_{2}$ the weighting coefficients; $g$ is the gravitational acceleration. The energy head loss $h_{e}$ specifies the effects of friction, as well as expansion and contraction caused by the channel geometry. At each crosssection, Manning's equation is used to compute discharge $Q$ (Eq. 2):

$Q=\frac{1}{n} A R^{2 / 3} S_{f}^{1 / 2}$

where $A$ is cross-section area, $R$ is the hydraulic radius, $S_{f}$ is the energy gradient, and $n$ is a hydraulic loss (or roughness) coefficient (Brunner, 2020a).

Geometric data for our HEC-RAS runs came from the 5-m resolution ALOS digital elevation model, projected to UTM Zone

$12544 \mathrm{~N}$ (Fig. 2). We also acquired field data with a TruPulse 360 laser range finder and a Garmin eTrex handheld GPS during two campaigns in October of 2016 and 2019. We used these field data to derive 572 channel cross-sections of the Seti Khola and its major tributaries from the DEM, especially in the narrow gorges (Fig. 1). The average spacing between cross-sections was $90 \mathrm{~m}$. We estimated Manning's $n$ from manual mapping of land-cover classes based on 1-m resolution Maxar satellite data (ESRI and Maxar Technologies, 2021) following guidelines by Brunner (2020b). We also estimated Manning's $n$ at 61

130 field locations following methods by Arcement Jr and Schneider (1984) and Chow (1959). We defined ten outburst discharge scenarios with peak discharge $1,000 \leq Q_{p} \leq 10,000 \mathrm{~m}^{3} \mathrm{~s}^{-1}$ in the main channel. This range covers monsoonal floods $(1,500$ to 2,300 $\mathrm{m}^{3} \mathrm{~s}^{-1}$; Basnet and Acharya, 2019) and also larger but rarer outbursts like the one in May $2012\left(8,400 \mathrm{~m}^{3} \mathrm{~s}^{-1}\right.$; Oi et al., 2014). The steepness of the Seti Khola's upper reach led us to specify mixed flow conditions with the critical flow depth as the upper boundary condition, while we set a normal depth of 0.0065 as the lower boundary condition. We assumed a constant base flow of $100 \mathrm{~m}^{3} \mathrm{~s}^{-1}$ (i.e. $10 \%$ of our lowest outburst scenario) in the Seti Khola's three likewise ungauged tributaries (Mardi Khola, Kali Khola, Phusre Khola). 


\subsection{Land-use and land-cover data}

Using 1-m Maxar satellite imagery acquired in 2020 (ESRI and Maxar Technologies, 2021), we manually mapped ten land cover (LC) classes in our model domain with an area of $136 \mathrm{~km}^{2}$ (Fig. 1). Following the USGS National Land Cover Database classification, we assigned the LC classes "developed, open", "developed - low (intensity)", "developed - medium (intensity)", "developed - high (intensity)”, “(open) water", "barren (land)”, "grassland(/herbaceous)” (might include grazing of livestock), “(cultivated) crops", "shrub (scrubs)", and "(mixed) forest". The different levels of "developed" LC classes are based on the percentage of area covered by impervious materials (built-up areas), i.e. <20\% in "developed, open" and highest (>80\%) in "developed - high (intensity)" areas (Multi-Resolution Land Characteristics Consortium, 2019). We also mapped "revegetated

145 floodplain", delineating the May 2012 flood's deposits and included in the "grassland(/herbaceous)" LC class, as well as the two land use (LU) classes "airport" and "sand and gravel mining". The latter is assigned to the "barren (land)" LC class.

We derived object-scale data on Pokhara city's buildings, as well as roads and footpaths from the OpenStreetMap (OSM) collaborative project (https://www.openstreetmap.org/) via the Overpass Turbo tool (https://overpass-turbo.eu/) to capture the situation in September 2021.

150 We mapped built-up areas in two informal settlements from medium- to high-resolution satellite imagery of April 2008 (Google Earth), November 2012 (Google Earth and RapidEye), and November 2021 (Google Earth and PlanetScope). In these images, we also identified sand and gravel mining activities based on the presence of artificial groynes and gravel heaps at the active channel margins.

\subsection{Potential flood impact analysis}

155 We used a geospatial overlay of our modelled flood inundation boundaries with the LULC data to assess on a semi-quantitative basis the likely impacts of ten peak discharge scenarios. We defined ten flood hazard classes by assigning areas and objects of the lowest scenario $\left(Q_{p}=1,000 \mathrm{~m}^{3} \mathrm{~s}^{-1}\right)$ to the highest hazard class (HC) 10. Conversely, the lowest hazard class 1 is attributed to areas and objects that would be inundated in the highest magnitude scenario $\left(Q_{p}=10,000 \mathrm{~m}^{3} \mathrm{~s}^{-1}\right)$.

160 To check the plausibility of our modelling results, we mapped the uppermost reach of the Seti Khola between Karuwa and Kharapani (Fig. 1), where the 2012 flood caused most damage. We used high-resolution Google Earth satellite imagery from December 2011 (pre-flood) and June 2012 (post-flood) to map man-made structures, including houses, huts, and temples. We also recorded the extent of sediment deposited during the May 2012 flood along this 8.4-km long reach from orthorectified 5m resolution RapidEye imagery of October 18, 2012. 


\section{Results}

\subsection{Impacts of the 2012 flood and outburst flood scenarios}

Our mapping of the impacts of the May 2012 outburst flood along the Seti Khola show that nearly $30 \%$ of the 145 man-made structures visible in satellite images before the flood were undetectable after. We estimate a loss in built-up area of $945 \mathrm{~m}^{2}$ or $14 \%$. In the most heavily affected reach near Kharapani, only five of the 29 buildings remained, while $60 \%$ of built-up area

was lost (Fig. 3). The best agreement between modelled inundation extent and observed flood sediment in this reach is for a simulated $Q_{\mathrm{p}}$ of $3,700 \mathrm{~m}^{3} \mathrm{~s}^{-1}$, which underestimates inundated areas by $13.5 \%$.

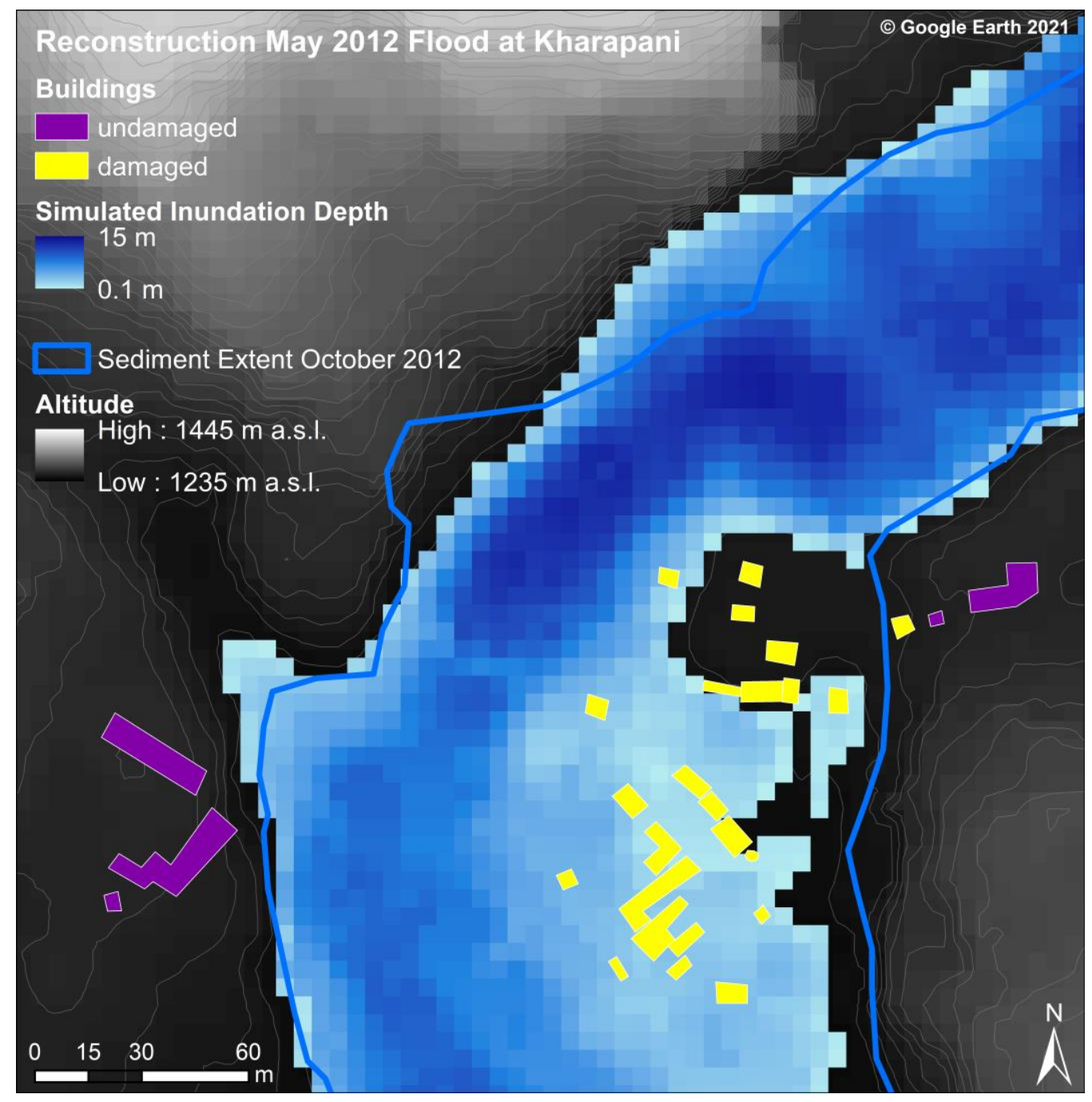

Figure 3: Simulated flow depths of the May 2012 flood at Kharapani village, assuming a flood peak of 3,700 m $\mathrm{s}^{-1}$. Blue lines delimit patches of flood-derived sediment mapped from RapidEye imagery (October 2012). Building damage is based on comparing Google Earth imagery of December 2011 and June 2012. 
Our scenario-based simulations reveal a spatially variable downstream pattern of areas potentially inundated by outbursts along the Seti Khola (Fig. 4). In the uppermost reach north of the Mardi Khola confluence, simulated flood extents are very similar for all scenarios but funnel out further downstream where the May 2012 flood deposited gravel sheets. Gravel bars near or below Kharapani are currently exploited for gravel mining and likely to be flooded in all scenarios; local flow depth be as much as $14 \mathrm{~m}$ for peak discharge $Q_{\mathrm{p}}$ of $10,000 \mathrm{~m}^{3} \mathrm{~s}^{-1}$ (Fig. 4).

Between the Mardi Khola and Kali Khola confluences, inundation would largely affect a number of informal settlements and infrastructure as well as the Seti dam, given that the lowermost river terrace would be extensively flooded for $Q_{\mathrm{p}}>3,000 \mathrm{~m}^{3} \mathrm{~s}$ ${ }^{1}$. One of these informal settlements at Yamdi would be inundated in all scenarios (Fig. 5), together with a major road connecting Pokhara with north-eastern Nepal. For another informal settlement at Kaseri, all flood scenarios indicate extensive flooding with a mean flow depth of $23 \mathrm{~m}$ and a mean flow velocity of $1.3 \mathrm{~m} \mathrm{~s}^{-1}$ for $Q_{\mathrm{p}}=10,000 \mathrm{~m}^{3} \mathrm{~s}^{-1}$ (Fig. 6).

Further downstream, Ramghat is another informal settlement and also a site of religious importance that could be affected by up to 32-m deep flows in the $Q_{\mathrm{p}}=10,000 \mathrm{~m}^{3} \mathrm{~s}^{-1}$ scenario. Flood-water levels could reach the edge of the uppermost terrace if $Q_{\mathrm{p}}>7,000 \mathrm{~m}^{3} \mathrm{~s}^{-1}$ and thus affect the surrounding dense urban areas (Fig. 4).

190 The less confined, meandering channel downstream of the Phusre Khola confluence has the largest variations in inundation areas in the Pokhara valley, and point bars mined for gravel or used for crop production are likely to be flooded at $Q_{\mathrm{p}}>6,000$ $\mathrm{m}^{3} \mathrm{~s}^{-1}$. We observe pronounced backwater flooding in at least three tributaries of the Seti Khola in all $Q_{\mathrm{p}}$ scenarios, likely inundating the lowest reaches of these tributaries for several hundred metres for $Q_{\mathrm{p}}>6,000 \mathrm{~m}^{3} \mathrm{~s}^{-1}$ (Fig. 4). Our results also indicate an isolated inundation in central Pokhara, some $1.5 \mathrm{~km}$ away from the Seti Khola and close to the Phirke Khola tributary (Fig. 4). 


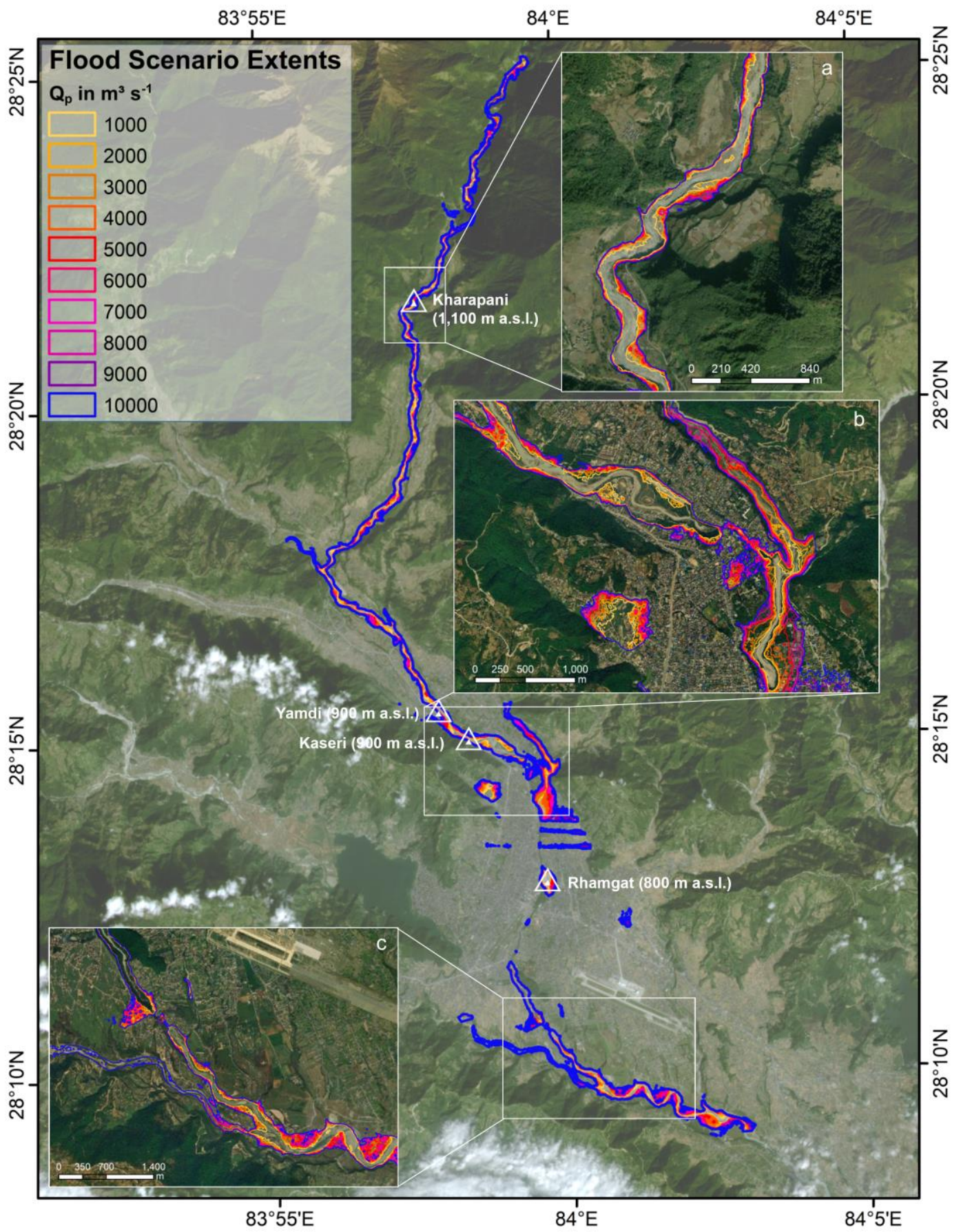

Figure 4: Flood extents for HEC-RAS modelling of steady flow with $Q_{\mathrm{p}}$ ranging from $1,000 \mathrm{~m}^{3} \mathrm{~s}^{-1}$ to $10,000 \mathrm{~m}^{3} \mathrm{~s}^{-1}$. Insets highlight results at Kharapani (a), Seti dam (b), and Phusre Khola confluence (c). Image: PlanetScope (13/11/2021) (Planet Team, 2017), inserts ESRI basemap Maxar imagery of 2020 (ESRI and Maxar Technologies, 2021). 

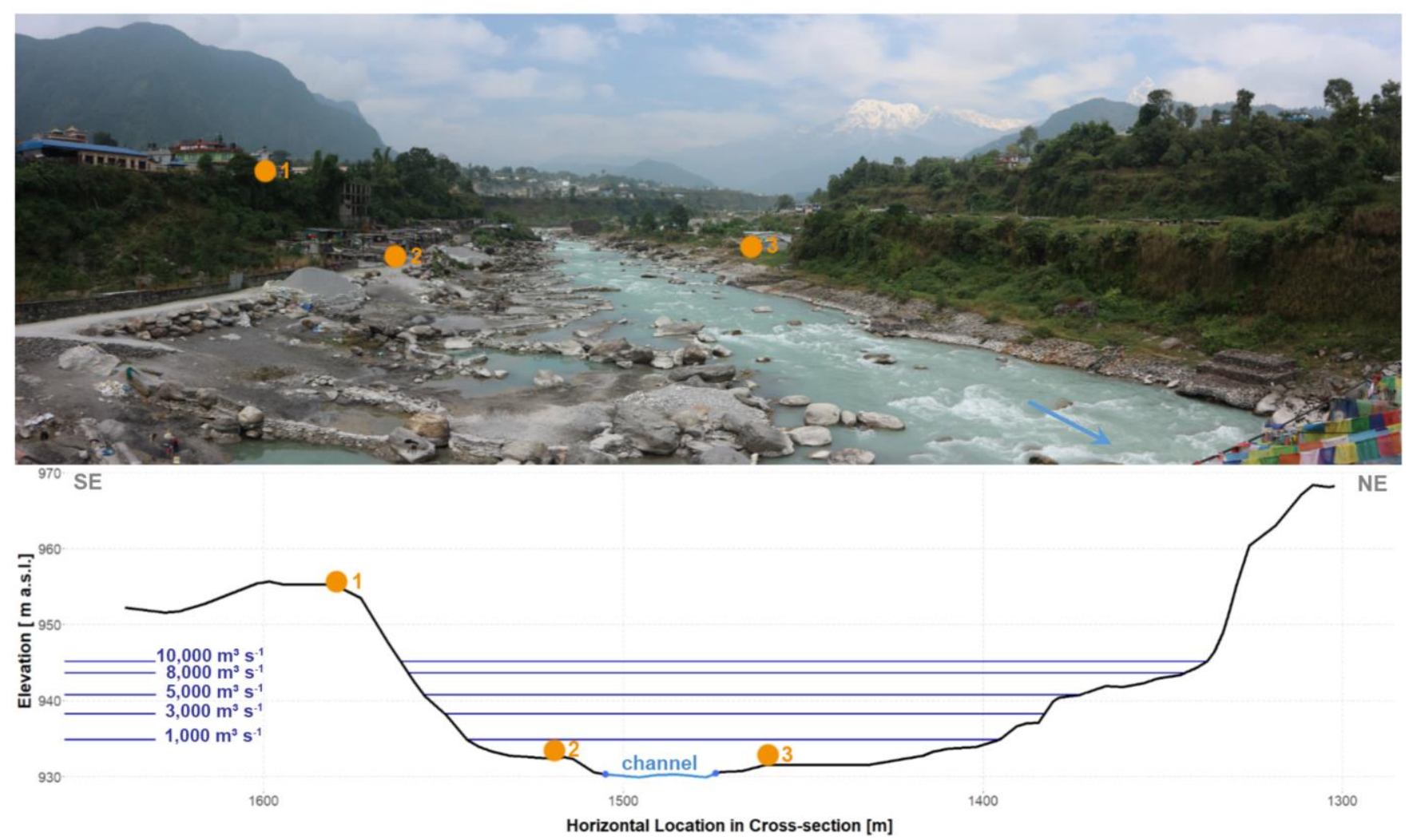

Figure 5: Simulated water-levels at an informal settlement and gravel mining site at Yamdi (Fig. 4) for five selected $Q_{p}$ scenarios. Buildings on overbank areas would be inundated in all modelled scenarios. Groynes and gravel heaps (in foreground) aid the detection of gravel mining activities from optical satellite images. 

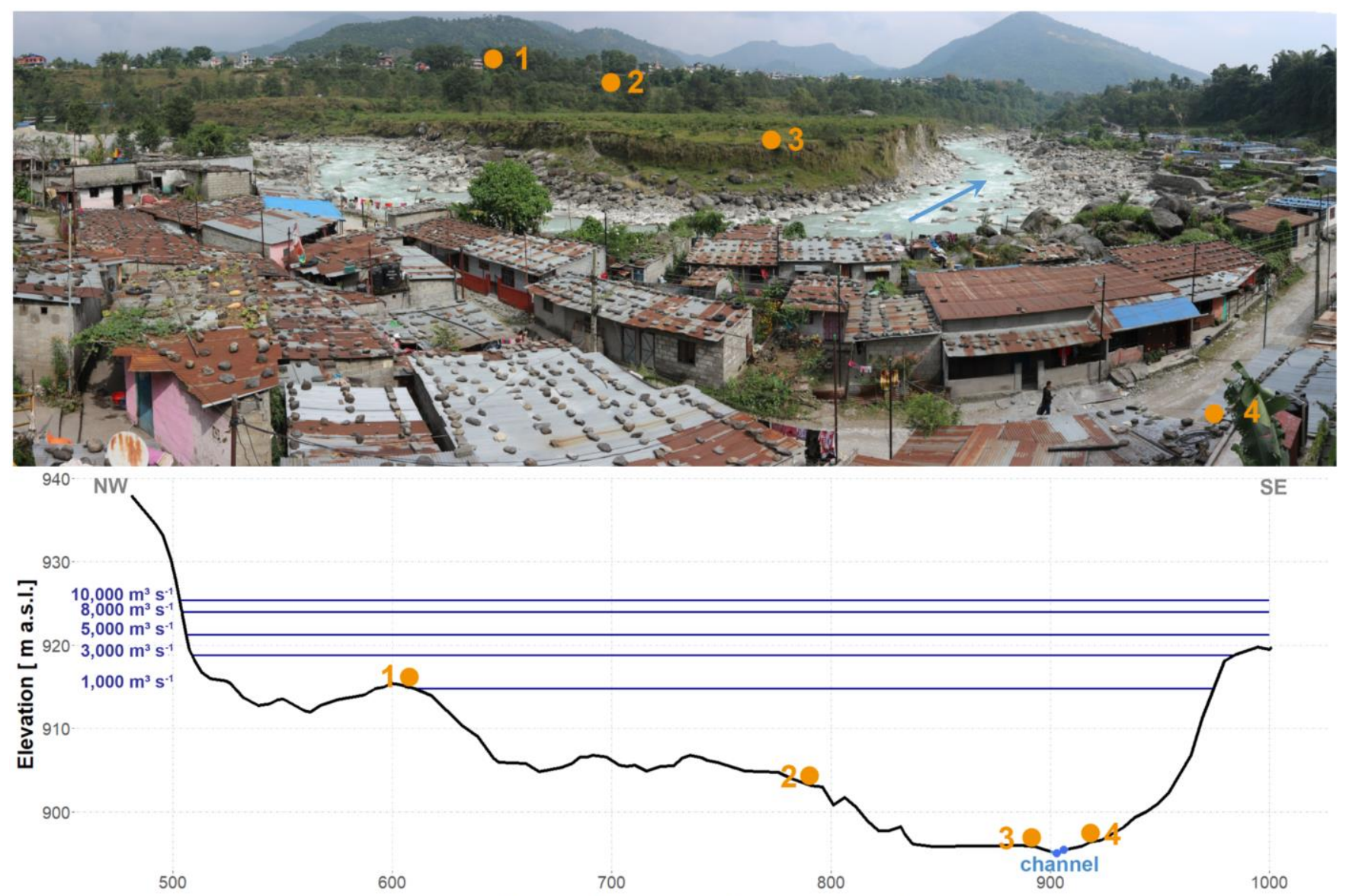

Figure 6: Simulated water-levels at the Kaseri informal settlement (Fig. 4) for five $Q_{p}$ scenarios. View from the edge of the settlement's core, which formed in the 1980's on a low terrace (Gurung et al., 2021), onto newer houses built close to the active channel bed of the Seti Khola.

\subsection{Potential future flood impacts}

In $2020,41 \%$ of the study area was covered by developed land, while mixed forest covered $27 \%$ mostly in the northern and southern parts (Fig. 7). Our simulations indicate that grassland, forests and barren classes (including heavily mined gravel bars) would be flooded widely in all $Q_{\mathrm{p}}$ scenarios (Table 1, Fig. 8). Some $0.5 \mathrm{~km}^{2}$ or $2.3 \%$ of the total crop area could be submerged for $Q_{\mathrm{p}}=10,000 \mathrm{~m}^{3} \mathrm{~s}^{-1}$. Of all developed LC classes, $0.3 \mathrm{~km}^{2}$ or $0.6 \%$ would be affected by a peak discharge $Q_{\mathrm{p}}$ of

$2151,000 \mathrm{~m}^{3} \mathrm{~s}^{-1}$, compared to $2.8 \%\left(1.5 \mathrm{~km}^{2}\right)$ for a peak discharge ten times higher. Low developed areas appear to be affected most extensively in all scenarios (Fig. 9). For the worst $Q_{\mathrm{p}}$ scenario, some $0.6 \mathrm{~km}^{2}$ of both low (2\%) and medium developed (4.1\%) area would be flooded, as opposed to $0.09 \mathrm{~km}^{2}(1 \%)$ and $0.25 \mathrm{~km}^{2}(2.8 \%)$ for the densest urban areas. Thus, most of 
https://doi.org/10.5194/nhess-2022-64

Preprint. Discussion started: 3 March 2022

(C) Author(s) 2022. CC BY 4.0 License.
Natural Hazards and Earth System Sciences

Discussions

the affected areas of the "developed - high" and "developed - open" classes are rated as hazard class 10 (Table 1, Fig. 9). Only airport areas seem completely devoid of flooding under the scenarios considered here.

Table 1: Hazard matrix listing the area (in $\left.\mathrm{m}^{2}\right)$ of each LULC class located within the respective hazard class (HC)

\begin{tabular}{|c|c|c|c|c|c|c|c|c|c|c|}
\hline Hazard Class & $\begin{array}{l}\text { Developed } \\
\text { - high }\end{array}$ & $\begin{array}{l}\text { Developed } \\
\text { - medium }\end{array}$ & $\begin{array}{l}\text { Developed } \\
\text { - low }\end{array}$ & $\begin{array}{l}\text { Developed } \\
\text { - open }\end{array}$ & Airport & Barren & Grassland & Crops & Shrub & Forest \\
\hline $\begin{array}{l}\text { HC } 10 \\
\left(Q_{p}=1,000 \mathrm{~m}^{3} \mathrm{~s}^{-1}\right)\end{array}$ & 88,404 & 49,981 & 146,863 & 47,781 & 0 & 785,620 & 890,852 & 49,427 & 261,705 & 592,295 \\
\hline $\begin{array}{l}\text { HC } 9 \\
\left(Q_{p}=2,000 \mathrm{~m}^{3} \mathrm{~s}^{-1}\right)\end{array}$ & 39,769 & 26,588 & 67,375 & 21,663 & 0 & 87,289 & 276,359 & 29,972 & 75,234 & 116,667 \\
\hline $\begin{array}{l}\mathrm{HC} 8 \\
\left(\mathrm{Q}_{p}=3,000 \mathrm{~m}^{3} \mathrm{~s}^{-1}\right)\end{array}$ & 24,472 & 18,408 & 63,907 & 3,297 & 0 & 49,084 & 203,291 & 33,648 & 64,760 & 88,116 \\
\hline $\begin{array}{l}\mathrm{HC} 7 \\
\left(\mathrm{Q}_{p}=4,000 \mathrm{~m}^{3} \mathrm{~s}^{-1}\right)\end{array}$ & 14,426 & 42,852 & 62,663 & 3,841 & 0 & 21,335 & 205,548 & 33,764 & 78,507 & 76,140 \\
\hline $\begin{array}{l}\text { HC } 6 \\
\left(Q_{p}=5,000 \mathrm{~m}^{3} \mathrm{~s}^{-1}\right)\end{array}$ & 11,086 & 50,432 & 44,528 & 2,766 & 0 & 15,639 & 183,582 & 45,584 & 52,529 & 86,229 \\
\hline $\begin{array}{l}\text { HC 5 } \\
\left(Q_{p}=6,000 \mathrm{~m}^{3} \mathrm{~s}^{-1}\right)\end{array}$ & 10,524 & 30,214 & 32,089 & 896 & 0 & 17,966 & 163,655 & 45,691 & 49,145 & 83,334 \\
\hline $\begin{array}{l}\mathrm{HC} 4 \\
\left(\mathrm{Q}_{p}=7,000 \mathrm{~m}^{3} \mathrm{~s}^{-1}\right)\end{array}$ & 10,997 & 46,156 & 33,134 & 90 & 0 & 11,522 & 158,692 & 51,518 & 45,704 & 64,897 \\
\hline $\begin{array}{l}\text { HC 3 } \\
\left(Q_{p}=8,000 \mathrm{~m}^{3} \mathrm{~s}^{-1}\right)\end{array}$ & 12,226 & 41,392 & 37,610 & 93 & 0 & 10,218 & 138,063 & 49,926 & 50,186 & 53,428 \\
\hline $\begin{array}{l}\text { HC } 2 \\
\left(Q_{p}=9,000 \mathrm{~m}^{3} \mathrm{~s}^{-1}\right)\end{array}$ & 16,247 & 129,499 & 46,675 & 85 & 0 & 6,737 & 111,848 & 66,802 & 42,282 & 49,208 \\
\hline $\begin{array}{l}\text { HC } 1 \\
\left(Q_{p}=10,000 \mathrm{~m}^{3} \mathrm{~s}^{-1}\right)\end{array}$ & 21,157 & 153,446 & 82,444 & 90 & 0 & 4,258 & 100,775 & 83,456 & 33,911 & 45,499 \\
\hline No hazard & $8,610,038$ & $13,799,295$ & $30,803,189$ & 619,173 & $2,056,873$ & 192,916 & $6,057,324$ & $20,772,845$ & $7,037,390$ & $35,073,597$ \\
\hline
\end{tabular}




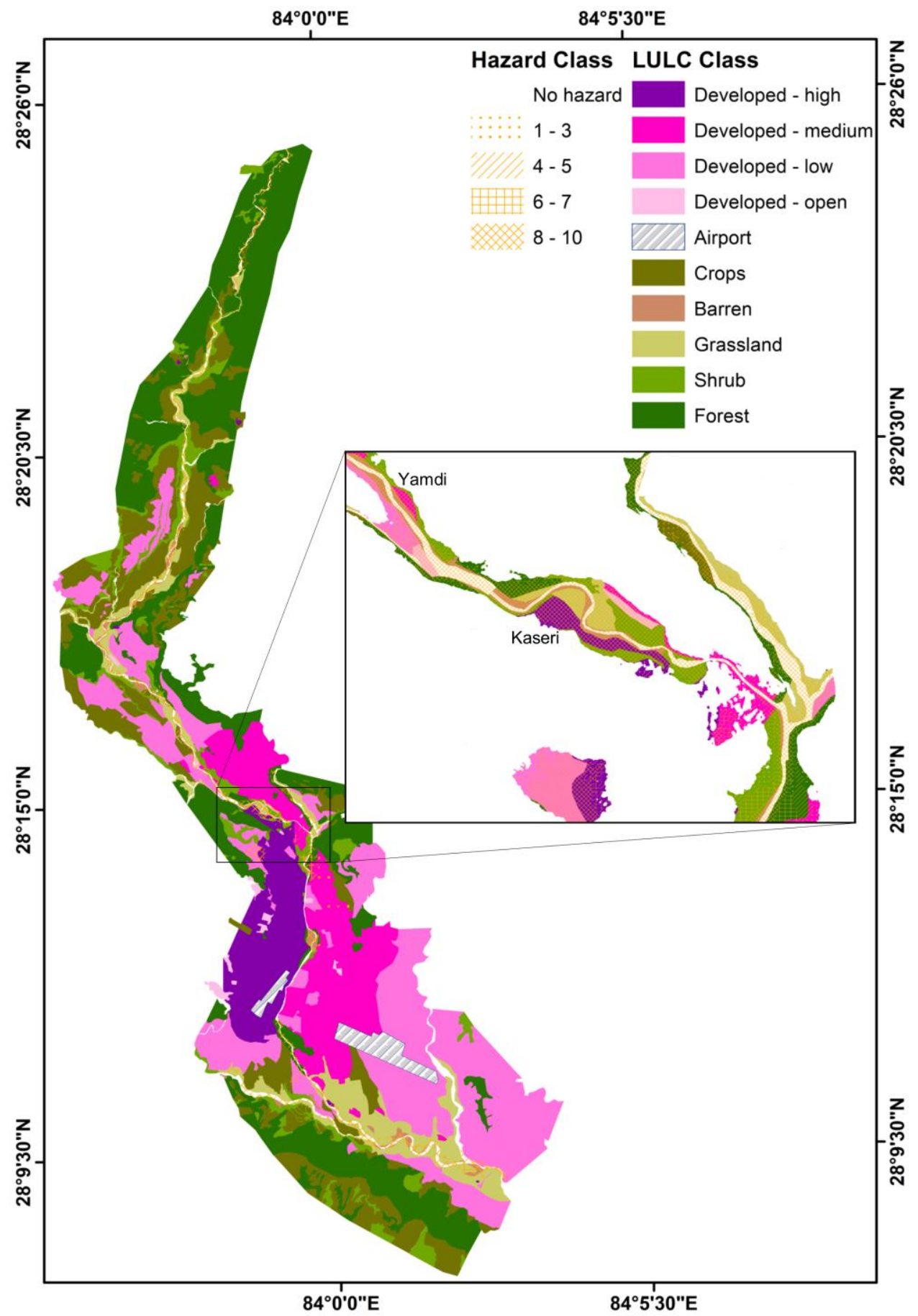

Figure 7: Land use and land cover (LULC) map with outburst flood hazard classes. Inset shows overlap of high hazard classes (HC 8 - 10) and densely populated areas (developed high to medium) at Yamdi and Kaseri informal settlements. LULC classes mapped from 2020 ESRI basemap Maxar imagery (ESRI and Maxar Technologies, 2021). 
https://doi.org/10.5194/nhess-2022-64

Preprint. Discussion started: 3 March 2022

(c) Author(s) 2022. CC BY 4.0 License.

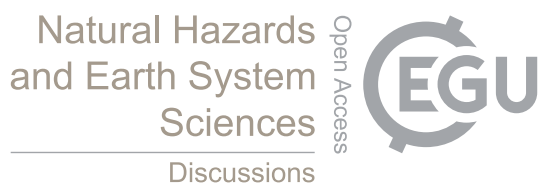

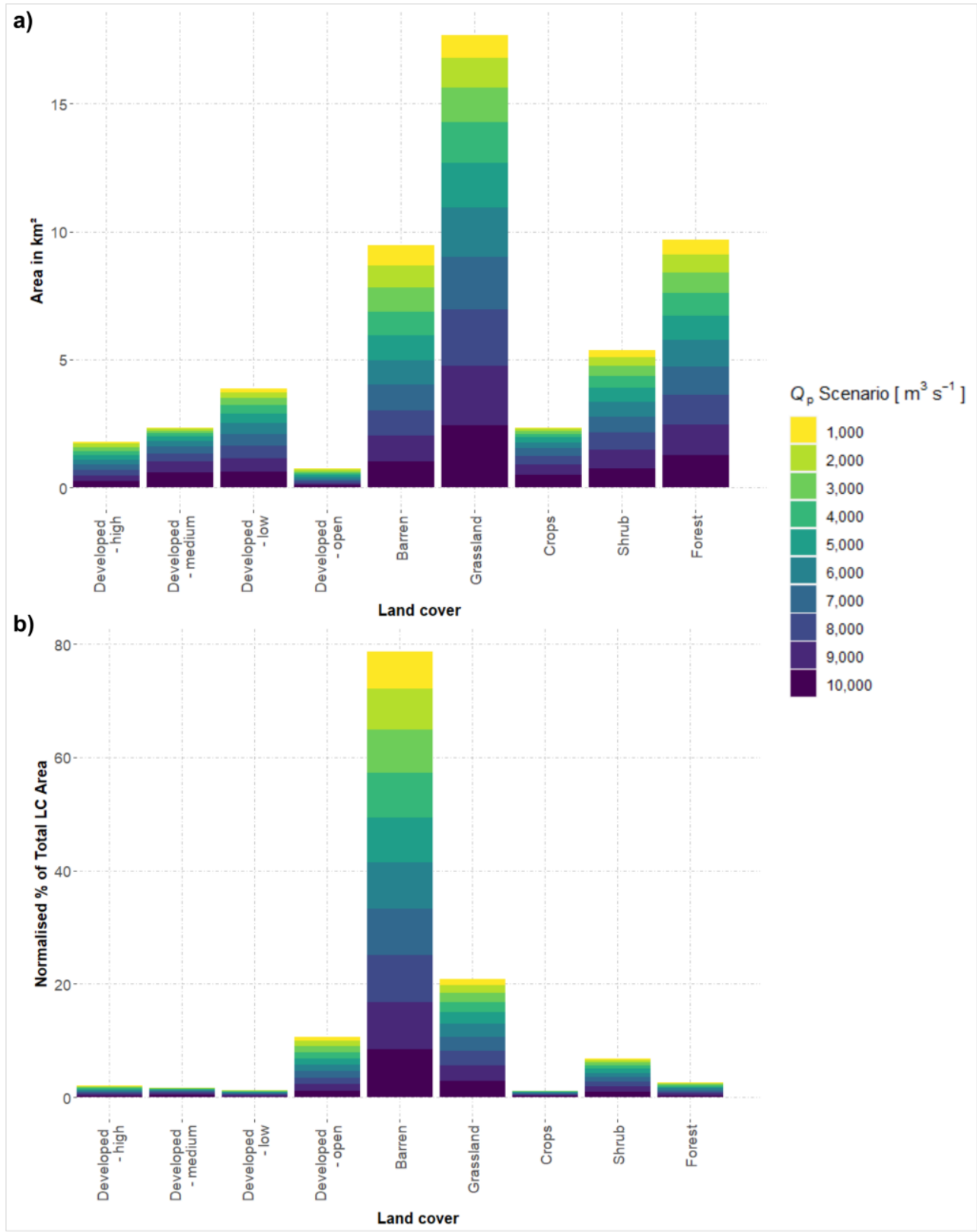

Figure 8: Results of the overlay of manually mapped land cover (LC) classes and $Q_{\mathrm{p}}$ Scenario inundation boundaries. a) Area of $L C$ class affected; b) affected normalised percentage of total mapped LC class areas in our study area. 


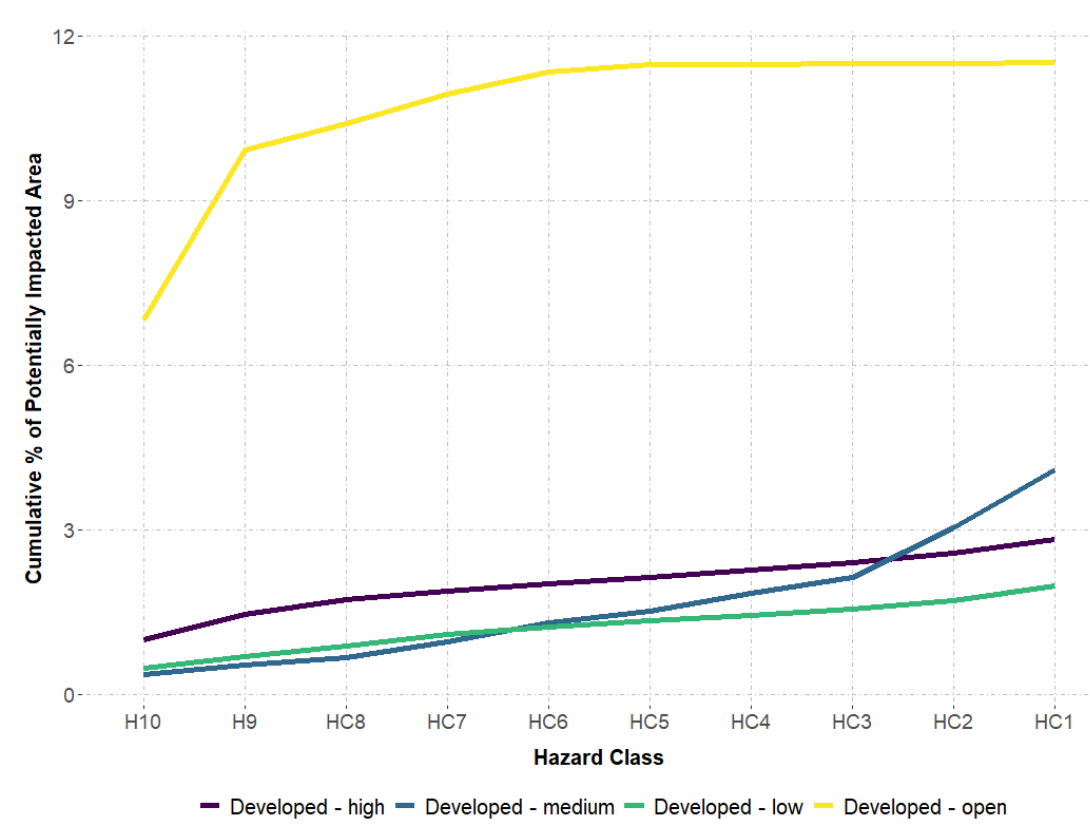

Figure 9: Each hazard class' cumulative percentage of areas at potential flood impact for each of the four developed LC classes.

235 Our analysis of the 2021 OSM route network shows that $4 \%$ of its length is prone to flooding, with $0.7 \%$ being in the highest hazard class 10 (Table 2, Fig. 10). Most roads and paths with HC >7 run along the upper Seti Khola upper reach, upstream of Kaseri.

As of September 2021, OSM users have mapped a total of 62930 buildings in Pokhara and $2.6 \%$ of these buildings and 2.5\% of the total built-up area are prone to flooding scenarios (Table 2, Fig. 11). A peak discharge of $10,000 \mathrm{~m}^{3} \mathrm{~s}^{-1}$ could affect 282 buildings $(0.5 \%)$, which translates to $0.3 \%\left(0.02 \mathrm{~km}^{2}\right)$ of the total built-up area falling into hazard class 10 . Many of the buildings categorized into the higher hazard classes (HC >7) are in Pokhara's north-western urban areas, especially in the Yamdi and Kaseri settlements.

Table 2: Relative hazard classification of the Pokhara route network and buildings. Data from OpenStreetMap (September 2021).

\begin{tabular}{|l|l|l|l|l|l|}
\hline \multirow{2}{*}{ Hazard Class } & \multicolumn{2}{|l|}{ Route Network } & Buildings \\
\cline { 2 - 6 } & Length $[\mathrm{km}]$ & $\%$ of total & No. Buildings & $\begin{array}{l}\text { Built-up area } \\
{\left[\mathrm{m}^{2}\right]}\end{array}$ & \% of total \\
\hline 10 & 32.0 & 0.74 & 282 & 21118 & 0.34 \\
\hline 9 & 19.3 & 0.45 & 145 & 12116 & 0.19 \\
\hline 8 & 15.1 & 0.35 & 81 & 6956 & 0.11 \\
\hline 7 & 13.5 & 0.31 & 118 & 10111 & 0.16 \\
\hline 6 & 15.2 & 0.35 & 105 & 8476 & 0.14 \\
\hline 5 & 15.2 & 0.35 & 63 & 6763 & 0.11 \\
\hline
\end{tabular}


https://doi.org/10.5194/nhess-2022-64

Preprint. Discussion started: 3 March 2022

(c) Author(s) 2022. CC BY 4.0 License.

Natural Hazards and Earth System Sciences

(c) ${ }_{\mathrm{BY}}$

\begin{tabular}{|l|l|l|l|l|l|}
\hline 4 & 13.4 & 0.31 & 73 & 8376 & 0.13 \\
\hline 3 & 13.0 & 0.30 & 88 & 8957 & 0.14 \\
\hline 2 & 16.8 & 0.39 & 250 & 28627 & 0.46 \\
\hline 1 & 19.0 & 0.44 & 409 & 42312 & 0.68 \\
\hline No hazard & 4160.5 & 96.02 & 61316 & 6074320 & 97.53 \\
\hline
\end{tabular}

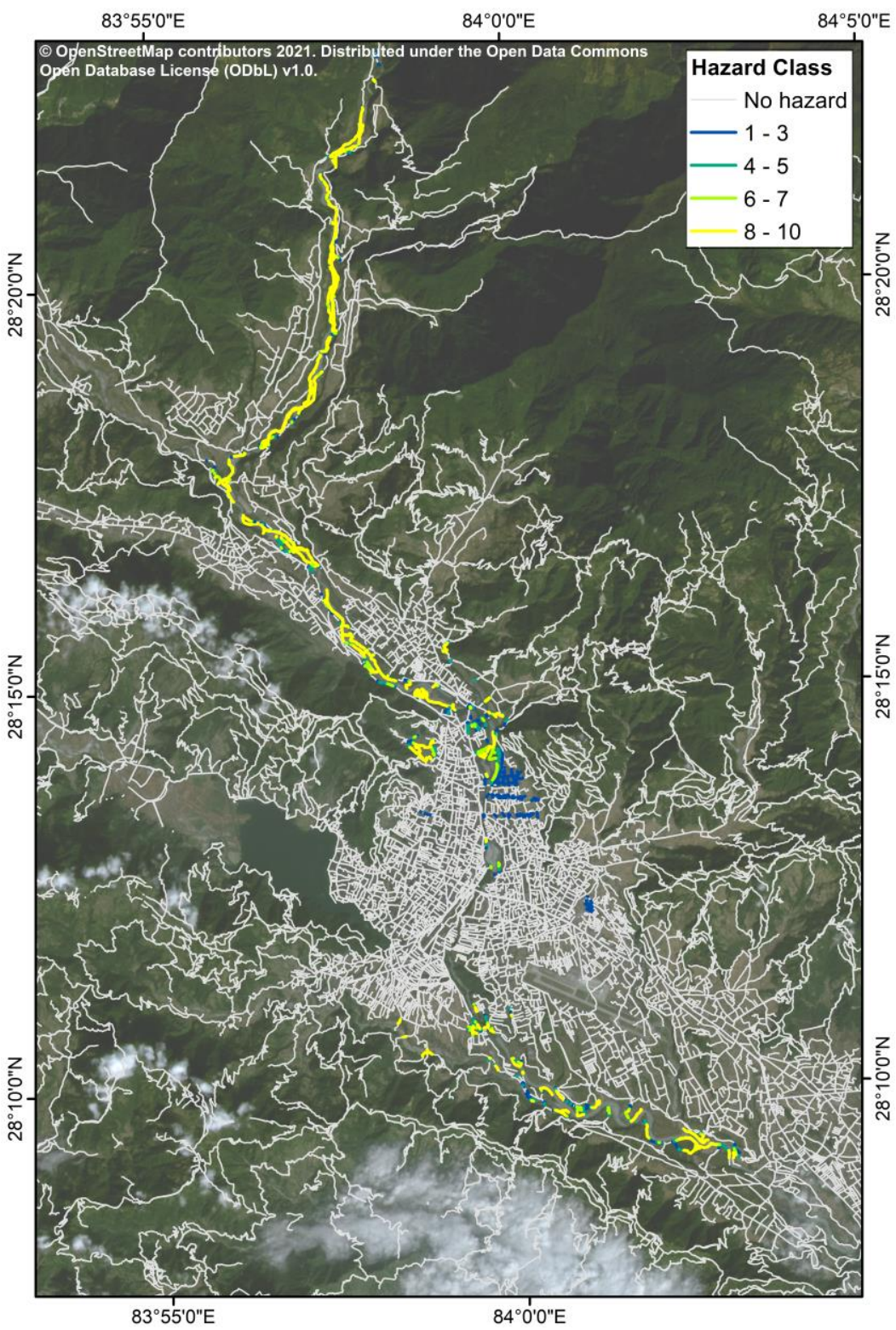

Figure 10: Relative hazard classification of the Pokhara route network. Data from OpenStreetMap in September 2021 and draped on PlanetScope imagery (13/11/2021) (Planet Team, 2017). 
https://doi.org/10.5194/nhess-2022-64

Preprint. Discussion started: 3 March 2022

(c) Author(s) 2022. CC BY 4.0 License.

\section{Natural Hazards and Earth System \\ Sciences \\ Discussions}

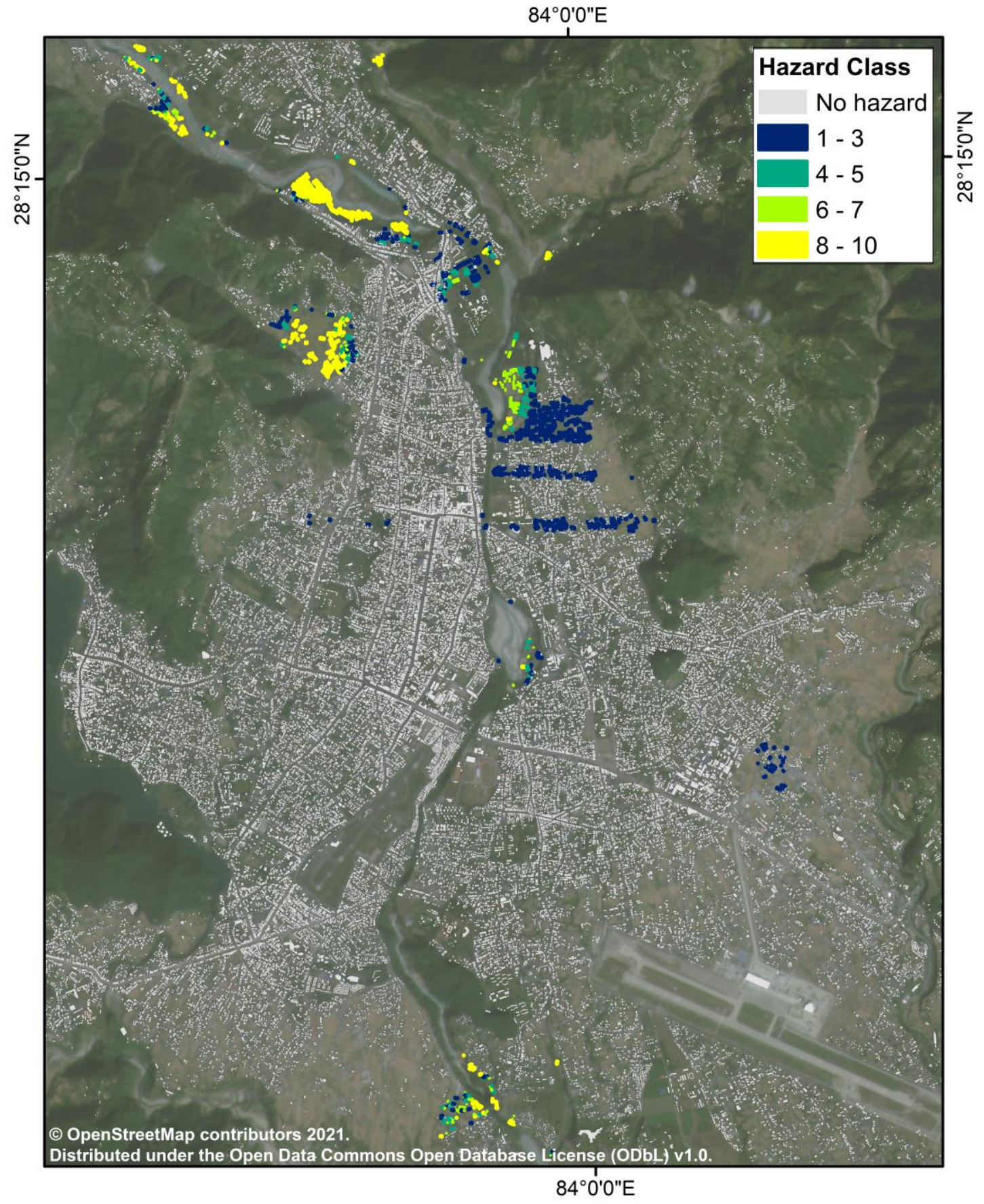

Figure 11: Relative hazard classification of Pokhara's mapped buildings. Data from OpenStreetMap (September 2021) draped on PlanetScope imagery (13/11/2021) (Planet Team, 2017). 
https://doi.org/10.5194/nhess-2022-64

Preprint. Discussion started: 3 March 2022

(c) Author(s) 2022. CC BY 4.0 License.

(c) (P)

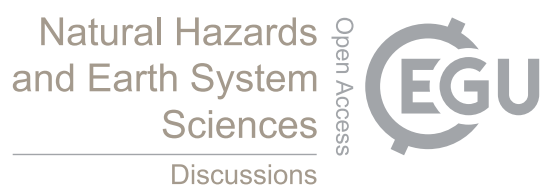

\subsection{Informal settlement dynamics}

The two informal settlements at Kaseri and Yamdi developed rapidly since 2008 (Table 3, Fig. 12). We find that Kaseri had expanded rapidly from a low terrace in 2008 towards the floodplain by 2012, thus more than doubling its built-up area. This 255 growth continued until at least 2021, covering more than a fifth of the overbank area. The built-up area at Yamdi covered a much lower proportion of overbank area in $2008(0.4 \%)$. Yet, growth was more rapid since, and the built- up area more than tripled between 2008 and 2012 and increased by a factor of six from 2012 to 2021. Comparing November 2012 and November 2021, we also observed a significant expansion of sand- and gravel mining in this particular reach.

260 Table 3: Growth of built-up areas of informal settlements at Kaseri and Yamdi, Pokhara, 2008 - 2021.

\begin{tabular}{|l|l|l|l|l|}
\hline \multirow{2}{*}{} & \multicolumn{2}{|l|}{ Kaseri } & \multicolumn{2}{l|}{ Yamdi } \\
\cline { 2 - 5 } & $\begin{array}{l}\text { Built-up area } \\
{\left[\mathrm{m}^{2}\right]}\end{array}$ & $\begin{array}{l}\text { \% of overbank } \\
\text { area }\end{array}$ & $\begin{array}{l}\text { Built-up area } \\
{\left[\mathrm{m}^{2}\right]}\end{array}$ & $\begin{array}{l}\text { of overbank } \\
\text { area }\end{array}$ \\
\hline Apr-2008 & 12092 & 7.3 & 726 & 0.4 \\
\hline Nov-2012 & 24886 & 15.1 & 2351 & 1.4 \\
\hline Nov-2021 & 36703 & 22.3 & 14848 & 9.1 \\
\hline
\end{tabular}




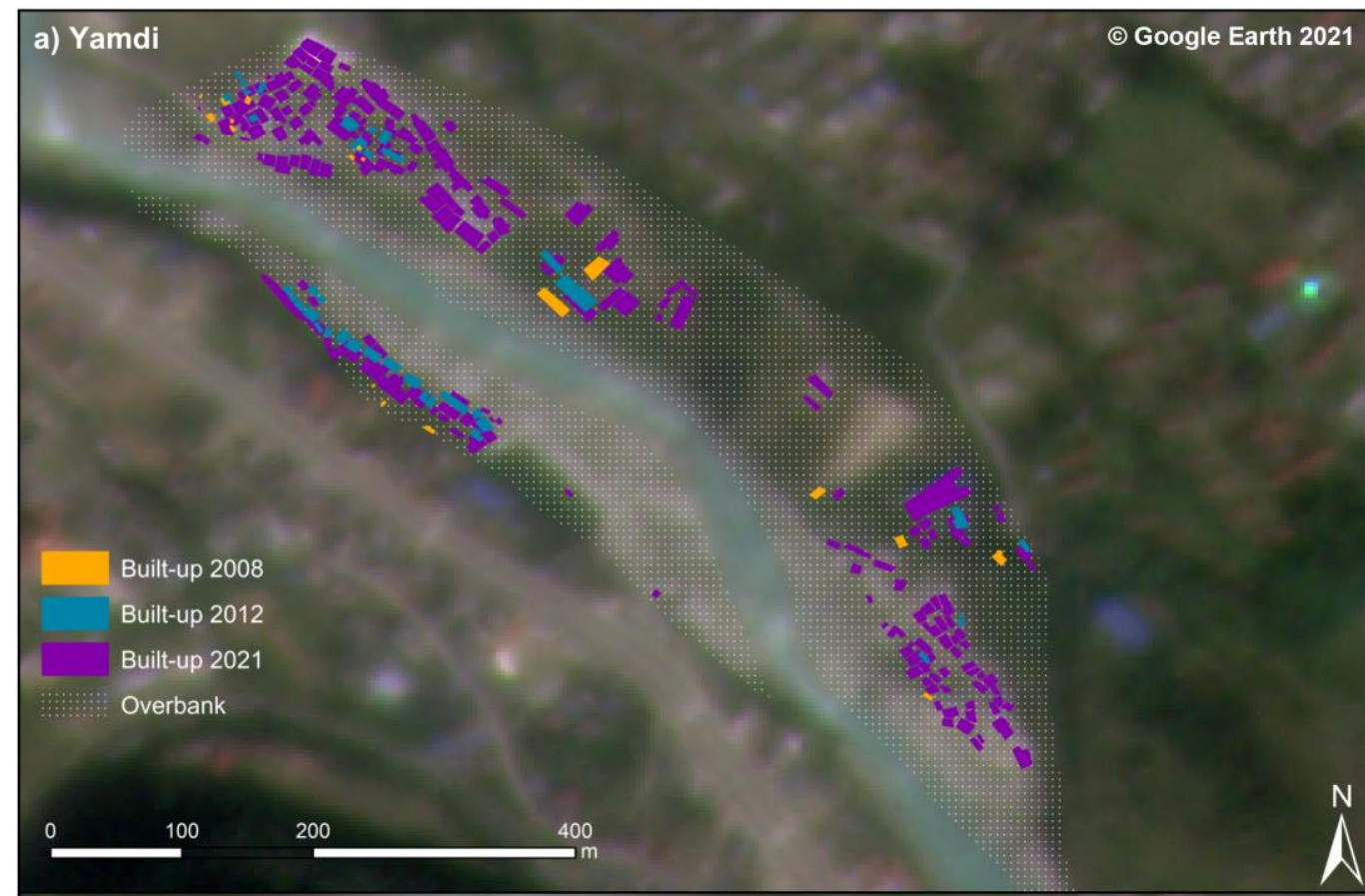

b) Kaseri

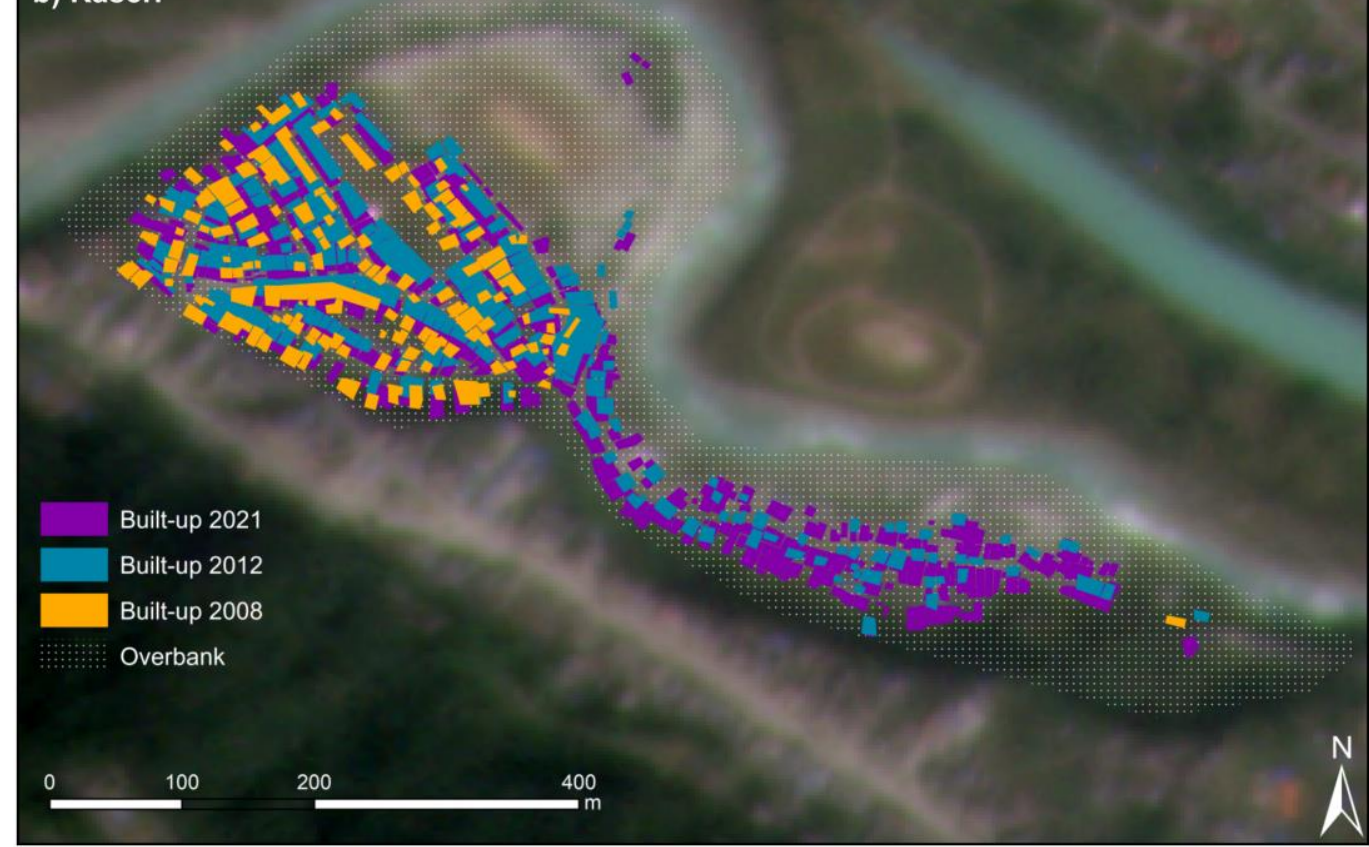

Figure 12: Changes in built-up area between April 2008 and November 2021 at Yamdi (a) and Kaseri (b) informal settlements. Builtup area mapped from Google Earth and draped on Planet Scope imagery (13/11/2021) (Planet Team, 2017). 


\section{Discussion}

\subsection{Inundation modelling}

Our scenario-based models of potential outburst flood impacts in Pokhara highlight that especially recent and rapidly growing informal settlements close to the active channel have a high likelihood of being inundated. Before we discuss the implications, we comment on the applicability of our methods. HEC-RAS has been widely applied to model outburst floods (Cenderelli and Wohl, 2003; Klimeš et al., 2014; Wang et al., 2018), albeit at the cost of simplifying outburst flood dynamics in terms of sediment content and channel-bed stability, as entrainment of sediments by bed erosion may alter flow rheology and runout (Westoby et al., 2014). Exact channel geometries are inaccessible in the high-alpine headwaters of the Seti Khola, thus curtailing the use of physically more advanced flow models. Although these could handle erosion and sedimentation dynamics in the propagation of sediment-laden flows, many of the required input parameters remain unconstrained (Cesca and D'Agostino, 2008; Westoby et al., 2014; Zhang and Liu, 2015). Hence, we restricted our scenario simulations to onedimensional steady flow.

The accuracy of our results hinges on the accuracy of river cross-sections and the estimates of channel and overbank roughness (Manning's $n$; Westoby et al., 2014; Wohl, 1998). Previous studies of HEC-RAS for outburst floods have used mostly coarser digital elevation data than the 5-m ALOS DEM we used here (Mergili et al., 2011; Somos-Valenzuela et al., 2014; Wang et al., 2018; Zhang and Liu, 2015). The stereo satellite imagery forming the basis for this DEM was acquired between 2006 and 2011 and excludes channel changes by the May 2012 flood (Gurung et al., 2021). We minimised potential resulting effects on our models by manually adjusting cross-sections with our additional field-surveyed elevation data. We tested the sensitivity of our HEC-RAS simulations related to the choice of Manning's $n$ by comparing the results of two $Q_{\mathrm{p}}=10,000 \mathrm{~m}^{3} \mathrm{~s}^{-1}$ scenario models, one with spatially varying and one with a constant Manning's $n$. Variations between these two models are minimal such that a spatially varied Manning's $n$ slightly improves the local accuracy of simulations. Yet these local improvements might be crucial in assessing flood hazard for the informal settlements near the Seti Khola. If the accuracy of our simulations of the May 2012 outburst is anything to go by, we surmise that our inundation scenarios are potential underestimates.

Our HEC-RAS simulations also show apparent flooding in places that are likely artefacts of the poorly resolved geometry of several narrow gorges and some subsurface drainage (Fig. 4). Sinkholes and caves in the Ghachok Formation may route some of the discharge of the Seti Khola below the surface, especially in urban areas (Fort, 2010; Rimal et al., 2015; Stolle et al., 2019). Modelling the groundwater flow in these potential karst structures is beyond the scope of this study and would require hydrological details that remain largely unresolved. We thus modelled flood flows for an idealized gorge geometry informed by DEM and field data. Hence, interpretation of these model artefacts has to be handled with care. 


\subsection{Flood scenarios and their potential impact}

Our results offer a first comprehensive set of outburst flood scenarios along the Seti Khola, and thus expand on previous studies of a more qualitative (Rimal et al., 2015, 2018) or local focus (Gurung et al., 2021; Thapa et al., 2022). By intersecting modelled inundation extents with spatial data on individual buildings and the route network, we are able to outline relative hazard zones on the assumption that smaller outburst flood magnitudes are more frequent than larger ones. We show that zones with higher relative flood hazard (HC >7) are mostly along the Seti Khola's upper reach. Despite the May 2012 flood's intense damage to infrastructure in this area, a number of infrastructure projects have been developed close to the Seti Khola, including several road bridges and a run-of-the-river hydroelectric station (Gurung et al., 2021).

Further downstream, our mapping of the recent spread of informal settlements along the Seti Khola at Kaseri and Yamdi between 2008 and 2021 substantiates residence interviews about this rapid growth (Gurung et al., 2021). We found that unregulated sand and gravel extraction at Yamdi has, like in many other Nepalese rivers, increased in past decades, but has especially accelerated after large amount of sediments were deposited by the May 2012 flood (Dahal et al., 2012; Fort et al., 2018). Our results illustrate the coupling of intense outburst flood sediment deposition and built-up area expansion along the Seti Khola's mid reaches, where more people were and still are attracted by this emerging opportunity of income. Although interviews with gravel and sand miners have shown that they are aware of this risk (Henzmann, 2020), they successively move into these flood-prone locations and raise their vulnerability to outburst floods. Gravel mining of this scale is likely to further modulate the roughness of the active channel, while enhancing bank erosion and cliff collapse, thus propagating the flood hazards also to the densely populated river terraces further up (Fort et al., 2018; Kondolf, 1994).

One key finding of our simulations is that hydraulic ponding upstream of gorges and backwater flooding at tributaries occurs in all scenarios, leading to high local flow depth and reduced flow velocities. The Seti dam and Kaseri informal settlement appear to be particularly prone to hydraulic ponding, which might cause severe flooding there. Locally sustained flood peaks might cause spatially much more diverse outburst flood hazard along this reach. While our models simulate clear-water flow, hydraulic ponding is likely exacerbated by entrained sediment and debris that may further clog or block the gorges (Thapa et al., 2022). Hydraulic ponding is a common process during outburst floods in bedrock or resistant-boundary channels and reported for Holocene jökulhlaups in Iceland (Carrivick, 2006, 2007) and historic outbursts of moraine-dammed lakes in British Columbia (Kershaw et al., 2005). This importance of hydraulic ponding complements the findings of previous studies concerned with estimating flood frequency at several sites (Basnet and Acharya, 2019; Gurung et al., 2021). Estimates of the 100 -year flood based on rainfall data are $Q_{\mathrm{p}}=2,336 \mathrm{~m}^{3} \mathrm{~s}^{-1}$ (Basnet and Acharya, 2019) and $Q_{\mathrm{p}}=2,423 \mathrm{~m}^{3} \mathrm{~s}^{-1}$ (Gurung et al., 2021). These are consistent with the lower range of outburst flood scenarios and offer comparable flood limits in the Rhamgat (Basnet and Acharya, 2019) and Kharapani areas (Gurung et al., 2021).

325 Overall, several studies have emphasised the potential for future outburst floods along the Seti Khola (Fort, 2010; Gurung et al., 2021; Kargel et al., 2013; Lovell et al., 2018). Especially the steep-walled and sediment-filled Sabche Cirque, above the narrow Seti Khola gorge, is geomorphically active and subject to rare, but strong earthquakes (Grandin et al., 2012). The upper 
Seti Khola gorge is a bottleneck prone to blockage by landslides detaching from the cirque walls (Kargel et al., 2013). Further downstream, landslides triggered by monsoonal storms (Talchabhadel et al., 2018) could also form temporary dams that might fail catastrophically like in the Melamchi outburst flood in June 2021 (Petley, 2021). Fort (1987) and Kargel et al. (2013) reported that the Sabche Cirque hosts large amounts of unconsolidated material to nourish floods and debris flows. New meltwater lakes in the Sabche Cirque may form outburst flood sources in the near future (Kargel et al., 2013). The Sabche glacier could also contribute to generating outburst floods during of following one of its surges (Lovell et al., 2018). One surge phase began in 2012, with the glacier having advanced by $2.2 \mathrm{~km}$ at up to $1.6 \pm 0.1 \mathrm{~m}$ per day (Lovell et al., 2018). Future research may want to explore possible links between surges and outburst flood potential along the Seti Khola.

\subsection{Recommendations}

No early-warning strategy was in place during the May 2012 outburst flood and several authors suggested that a chance warning presumably prevented a higher death toll in the north-western outskirts of Pokhara (Gurung et al., 2015; Kargel et al., 2013). In the flood's immediate aftermath, public flood risk awareness and preparation trainings as well as an early-warning system were implemented - including a water-level sensor in the Seti Khola just above the furthest upstream settlement (Gurung et al., 2015). However, recent interviews with local residents showed that a lack of maintenance has rendered the early warning system inoperable in the past years (Henzmann, 2020). Thapa et al. (2022) pointed out, that existing evacuation routes from Yamdi and Kaseri settlements towards higher ground are inadequate. A regularly maintained warning system might want to provide full coverage of settlements along the Seti Khola's course through the Pokhara valley and include the four major components of risk knowledge, monitoring and warning, dissemination and communication, and response capability (Huggel et al., 2020). The May 2012 flood also demonstrated that outburst floods can travel fast in the steep headwaters of the Seti Khola (Kargel et al., 2013; Oi et al., 2014). Stream gauges and comparable monitoring stations may need to be located further upstream than presently implemented, ideally close to the outlet of Sabche Cirque to maximise warning times for downstream communities. Continued monitoring of the Sabche Cirque using optical and SAR satellite data acquired at short repeat rates afforded via the Sentinel and Planet platforms might further assist early warning, while ground movement and deformations of the cirques walls, surge-phases of the Sabche glacier, and lake formation might be tell-tale warning signs (Grebby et al., 2021; Hermle et al., 2021; Kirschbaum et al., 2019; Quincey et al., 2005).

\section{Conclusions}

355 The Seti Khola is the lifeline of Nepal's second largest city, but also a river prone to outburst floods, given that it traverses one of the steepest topographic gradients in the Higher Himalayas. We provide the first comprehensive assessment of potential outburst discharge scenarios and intersect hydrodynamically modelled inundation extents with land-cover data. Our 
simulations demonstrate the high spatial variability of potential outburst flood impacts in the Pokhara valley. All model runs point to potential hydraulic ponding with high flow depths and low flow velocities above deeply incised gorges in urban areas. We find that even a moderate outburst flood scenario with peak discharge well within the ranges of monsoonal floods $\left(Q_{\mathrm{p}}=\right.$ $\left.1,000 \mathrm{~m}^{3} \mathrm{~s}^{-1}\right)$, could inundate some $0.6 \%\left(0.3 \mathrm{~km}^{2}\right)$ of the developed area and $3.2 \%$ of cropland and grassland. A larger outburst flood involving a peak discharge ten times higher would flood $2.8 \%\left(1.5 \mathrm{~km}^{2}\right)$ of the Pokhara valley's developed areas and 9.8\% of its agricultural areas. OSM data of built-up area in Pokhara's urban areas show, that relative inundation hazard is highest in the city's north-western outskirts, where a rapidly growing number of informal buildings linked to gravel mining is has moved close to the Seti Khola. These sites of extensive unregulated sand and gravel mining would be extensively inundated in all our discharge scenarios - putting workers and informal settlement dwellers at risk. Built-up area in both Kaseri and Yamdi has grown intensively in the past decade: While built-up area in Kaseri, Pokhara's oldest established informal settlement, tripled between 2008 and 2021, built-up area rapidly increased by a factor of 20 in the recently forming settlements at Yamdi. Since 2012, a sixfold increase in built-up area at the latter is accompanied by an intense expansion of gravel and sand mining activities. Several roads that are crucial for the supply reliability of rural communities are also prone to more frequent flooding by outbursts as these roads run parallel to the Seti Khola on its lower alluvial terraces.

We conclude that urban planning and risk mitigation strategies in the Pokhara valley might wish to consider the hazard posed by outburst floods in more detail, given the accumulating evidence of repeated historic and prehistoric events. Potential risk reduction measures may include in-field and remote monitoring of the Seti Khola's headwaters as well as early-warning strategies, including a statutorily determined chain of warning as well as public awareness training. Such training could be aided by considering scenario-based limits of inundation for different flood sources.

\section{Data availability}

All field data was submitted to the PANGEA Data Publisher for Earth \& Environmental Science (https://www.pangaea.de/) on 01/12/2021 and will be freely available after publication. ALOS WORLD 3D Topographic Data was provided by the Remote Sensing Technology Center of Japan (@NTT DATA, RESTEC/ Included@JAXA). PlanetScope and RapidEye satellite imagery was freely provided through the Education and Research Program of Planet Lab Inc. (https://www.planet.com/explorer). Data from the OpenStreetMap project are freely available via https://www.openstreetmap.org/ and https://overpass-turbo.eu/. We further used the freeware HEC-RAS 5.0.7, which is available under https://www.hec.usace.army.mil/software/hec-ras/, and Google Earth Pro 


\section{Author contributions}

Me.F., A.W., O.K., and S.R. conceptualised the study. The field data were collected by Me.F. and O.K. while Me.F. and J.B. curated field and additional data. All data were processed and visualised by Me.F. Me.F. prepared the original manuscript, which was reviewed and edited by A.W., S.R., Mo.F. and O.W.

\section{Competing interests}

The authors declare that they have no conflict of interest.

\section{Acknowledgements}

This research was supported by the Deutsche Forschungsgemeinschaft (DFG) via the graduate research training group

395 NatRiskChange at the University of Potsdam (https://www.natriskchange.de). The authors thank Georg Veh, Elisabeth Schönfeldt, and Narayan Gurung for their support during fieldwork and Natalie Lützow for data support with HEC-RAS.

\section{Financial support}

This study was financed by the Deutsche Forschungsgemeinschaft (GRK 2043/1 and 2043/2).

\section{References}

400 Arcement Jr, G. J. and Schneider, V. R.: Guide for selecting Manning's roughness coefficients for natural channels and flood plains: U.S. Geological Survey Water Supply Paper 2339, US Department of Transportation, Federal Highway Administration., 1984.

Basnet, K. and Acharya, D.: Flood Analysis at Ramghat, Pokhara, Nepal Using HEC-RAS, Tech. J., 1(1), 41-53, doi:10.3126/tj.v1i1.27591, 2019.

405 Brunner, G. W.: HEC-RAS, River Analysis System - Hydraulic Reference Manual, , 520, 2020a.

Brunner, G. W.: HEC-RAS River Analysis System - 2D Modeling User’s Manual, , 283, $2020 \mathrm{~b}$.

Carrivick, J. L.: Application of 2D hydrodynamic modelling to high-magnitude outburst floods: An example from Kverkfjöll, Iceland, J. Hydrol., 321(1-4), 187-199, doi:10.1016/j.jhydrol.2005.07.042, 2006.

Carrivick, J. L.: Modelling coupled hydraulics and sediment transport of a high-magnitude flood and associated landscape 
https://doi.org/10.5194/nhess-2022-64

Preprint. Discussion started: 3 March 2022

(c) Author(s) 2022. CC BY 4.0 License.

(c) (i)

change, Ann. Glaciol., 45, 143-154, doi:10.3189/172756407782282480, 2007.

Cenderelli, D. A. and Wohl, E. E.: Flow hydraulics and geomorphic effects of glacial-lake outburst floods in the Mount Everest region, Nepal, Earth Surf. Process. Landforms, 28(4), 385-407, doi:10.1002/esp.448, 2003.

Central Bureau of Statistics: National Census 2021, Natl. Census 2021 [online] Available from: https://cbs.gov.np/ (Accessed 21 February 2022), 2022.

415 Cesca, M. and D'Agostino, V.: Comparison between FLO-2D and RAMMS in debris-flow modelling: A case study in the Dolomites, WIT Trans. Eng. Sci., 60, 197-206, doi:10.2495/DEB080201, 2008.

Chow, V. T.: Open-channel hydraulics, McGraw-Hill Civ. Eng. Ser., 1959.

Dahal, K. R., Sharma, S. and Sharma, C. M.: A Review of Riverbed Extraction and its Effects on Aquatic Environment with Special Reference to Tinau River, Nepal, Hydro Nepal J. Water, Energy Environ., 11(Ddc), 49-56, doi:10.3126/hn.v11i0.7163, 4202012.

ESRI and Maxar Technologies: World Imagery, [online] Available from: https://services.arcgisonline.com/ArcGIS/rest/services/World_Imagery/MapServer, 2021.

Fort, M.: Sporadic morphogenesis in a continental subduction setting: an example from the Annapurna Range, Nepal Himalaya., Zeitschrift fur Geomorphol. Suppl., 63, 9-36, 1987.

425 Fort, M.: The Pokhara Valley: A product of a natural catastrophe, in Geomorphological Landscapes of the World, edited by P. Migon, pp. 265-274, Springer Science+Business Media B. V., 2010.

Fort, M.: Impact of climate change on mountain environment dynamics, Rev. géographie Alp., (103-2), 0-7, doi:10.4000/rga.2877, 2015.

Fort, M., Adhikari, B. R. and Rimal, B.: Chapter 12 - Pokhara (Central Nepal): A Dramatic Yet Geomorphologically Active 430 Environment Versus a Dynamic, Rapidly Developing City, in Urban Geomorphology, edited by M. J. Thornbush and C. D. Allen, pp. 231-258, Elsevier., 2018.

Gabet, E. J., Burbank, D. W., Putkonen, J. K., Pratt-Sitaula, B. A. and Ojha, T.: Rainfall thresholds for landsliding in the Himalayas of Nepal, Geomorphology, 63(3-4), 131-143, doi:10.1016/j.geomorph.2004.03.011, 2004.

Grandin, R., Doin, M. P., Bollinger, L., Pinel-Puysségur, B., Ducret, G., Jolivet, R. and Sapkota, S. N.: Long-term growth of 
https://doi.org/10.5194/nhess-2022-64

Preprint. Discussion started: 3 March 2022

(c) Author(s) 2022. CC BY 4.0 License.

the Himalaya inferred from interseismic InSAR measurement, Geology, 40(12), 1059-1062, doi:10.1130/G33154.1, 2012.

Grebby, S., Sowter, A., Gee, D., Athab, A., De la Barreda-Bautista, B., Girindran, R. and Marsh, S.: Remote monitoring of ground motion hazards in high mountain terrain using insar: A case study of the lake sarez area, tajikistan, Appl. Sci., 11(18), doi:10.3390/app11188738, 2021.

Gurung, D. R., Maharjan, S. B., Khanal, N. R., Joshi, G. and Murthy, M. S. R.: Nepal disaster report 2015, , 270, doi:10.1017/CBO9781107415324.004, 2015.

Gurung, N., Fort, M., Bell, R., Arnaud-Fassetta, G. and Maharjan, N. R.: Hydro-torrential hazard vs. anthropogenic activities along the Seti valley, Kaski, Nepal: Assessment and recommendations from a risk perspective, J. Nepal Geol. Soc., 62, 5887, doi:10.3126/jngs.v62i0.38695, 2021.

Hanisch, J., Koirala, A. and Bhandary, N. P.: The Pokhara May 5th flood disaster: a last warning sign sent by nature?, J. Nepal

Geol. Soc., 46, 1-10, 2013.

Henzmann, I.: Local Peoples Risk Perception of Natural Hazards in the Seti River Valley, Nepal, University of Zurich., 2020.

Hermle, D., Keuschnig, M., Hartmeyer, I., Delleske, R. and Krautblatter, M.: Timely prediction potential of landslide early warning systems with multispectral remote sensing: A conceptual approach tested in the Sattelkar, Austria, Nat. Hazards Earth Syst. Sci., 21(9), 2753-2772, doi:10.5194/nhess-21-2753-2021, 2021.

450 Hock, R., Rasul, G., Adler, C., Cáceres, B., Gruber, S., Hirabayashi, Y., Jackson, M., Kääb, A., Kang, S., Kutuzov, S., Milner, A., Molau, U., Morin, S., Orlove, B. and Steltzer, H. I.: High Mountain Areas, Genf., 2019.

Huggel, C., Cochachin, A., Drenkhan, F., Fluixá-Sanmartín, J., Frey, H., García Hernández, J., Jurt, C., Muñoz, R., Price, K. and Vicuña, L.: Glacier Lake 513, Peru: Lessons for early warning service development, WMO Bull., 69(1), 45-52 [online] Available from: https://library.wmo.int/doc_num.php?explnum_id=10223, 2020.

Immerzeel, W. W., Van Beek, L. P. H. and Bierkens, M. F. P.: Climate change will affect the asian water towers, Science (80. )., 328(5984), 1382-1385, doi:10.1126/science.1183188, 2010.

Kargel, J. S., Paudel, L., Leonard, G., Regmi, D., Joshi, S., Poudel, K., Thapa, B., Watanabe, T. and Fort, M.: Causes and human impacts of the Seti River (Nepal) disaster of 2012, in Glacial Flooding \& Disaster Risk Management Knowledge Exchange and Field Training; High Mountains Adaptation Partnership: Huaraz, Peru, pp. 1-11, Huaraz., 2013.

460 Kershaw, J. A., Clague, J. J. and Evans, S. G.: Geomorphic and sedimentological signature of a two-phase outburst flood from 
https://doi.org/10.5194/nhess-2022-64

Preprint. Discussion started: 3 March 2022

(c) Author(s) 2022. CC BY 4.0 License.

(c) (i)

moraine-dammed Queen Bess Lake, British Columbia, Canada, Earth Surf. Process. Landforms, 30(1), 1-25, doi:10.1002/esp.1122, 2005.

Kirschbaum, D., Watson, C. S., Rounce, D. R., Shugar, D. H., Kargel, J. S., Haritashya, U. K., Amatya, P., Shean, D., Anderson, E. R. and Jo, M.: The State of Remote Sensing Capabilities of Cascading Hazards Over High Mountain Asia, Front. Earth Sci., 7(September), doi:10.3389/feart.2019.00197, 2019.

Klimeš, J., Benešová, M., Vilímek, V., Bouška, P. and Cochachin Rapre, A.: The reconstruction of a glacial lake outburst flood using HEC-RAS and its significance for future hazard assessments: An example from Lake 513 in the Cordillera Blanca, Peru, Nat. Hazards, 71(3), 1617-1638, doi:10.1007/s11069-013-0968-4, 2014.

Kondolf, G. M.: Geomorphic and environmental effects of instream gravel mining, Landsc. Urban Plan., 28(2-3), 225-243, doi:10.1016/0169-2046(94)90010-8, 1994.

Lovell, A. M., Carr, J. R. and Stokes, C. R.: Topographic controls on the surging behaviour of Sabche Glacier, Nepal (1967 to 2017), Remote Sens. Environ., 210, 434-443, doi:10.1016/j.rse.2018.03.036, 2018.

Mergili, M., Schneider, D., Worni, R. and Schneider, J. F.: Glacial lake outburst floods in the Pamir of Tajikistan: Challenges in prediction and modelling, Int. Conf. Debris-Flow Hazards Mitig. Mech. Predict. Assessment, Proc., 973-982, doi:10.4408/IJEGE.2011-03.B-106, 2011.

Multi-Resolution Land Characteristics (MRLC) Consortium: National Land Cover Database 2019 (NLCD2019) Legend, NLCD2019 [online] Available from: https://www.mrlc.gov/data/legends/national-land-cover-database-2019-nlcd2019-legend (Accessed 12 January 2022), 2019.

Nussbaumer, S., Schaub, Y., Huggel, C. and Walz, A.: Risk estimation for future glacier lake outburst floods based on local land-use changes, Nat. Hazards Earth Syst. Sci., 14(6), 1611-1624, doi:10.5194/nhess-14-1611-2014, 2014.

Oi, H., Higaki, D., Yagi, H., Usuki, N. and Yoshino, K.: Report of the investigation of the flood disaster that occurred on May 5, 2012 along the Seti River in Nepal, Int. J. Eros. Control Eng., 7(4), 111-117, doi:10.13101/ijece.7.111, 2014.

Petley, D.: Melamchi: a landslide dam break flood in Nepal last week, Landslide Blog - AGU Blogosph. [online] Available from: https://blogs.agu.org/landslideblog/2021/06/21/melamchi-a-landslide-dam-break-flood-in-nepal-last-week/ (Accessed 48516 July 2021), 2021.

Planet Team: Planet Application Program Interface: In Space for Life on Earth, [online] Available from: https://www.planet.com/explorer, 2017. 
https://doi.org/10.5194/nhess-2022-64

Preprint. Discussion started: 3 March 2022

(c) Author(s) 2022. CC BY 4.0 License.

Quincey, D. J., Lucas, R. M., Richardson, S. D., Glasser, N. F., Hambrey, M. J. and Reynolds, J. M.: Optical remote sensing techniques in high-mountain environments: Application to glacial hazards, Prog. Phys. Geogr., 29(4), 475-505, doi:10.1191/0309133305pp456ra, 2005.

Rimal, B.: Urbanization and the Decline of Agricultural Land in Pokhara Sub-metropolitan City, Nepal, J. Agric. Sci., 5(1), 54-65, doi:10.5539/jas.v5n1p54, 2012.

Rimal, B., Baral, H., Stork, N., Paudyal, K. and Rijal, S.: Growing City and Rapid Land Use Transition: Assessing Multiple Hazards and Risks in the Pokhara Valley, Nepal, Land, 4(4), 957-978, doi:10.3390/land4040957, 2015.

Rimal, B., Zhang, L., Keshtkar, H., Sun, X. and Rijal, S.: Quantifying the spatiotemporal pattern of urban expansion and hazard and risk area identification in the Kaski District of Nepal, Land, 7(1), doi:10.3390/land7010037, 2018.

Ross, J. and Gilbert, R.: Lacustrine sedimentation in a monsoon environment: The record from Phewa Tal, middle mountain region of Nepal, Geomorphology, 27(3-4), 307-323, doi:10.1016/S0169-555X(98)00079-8, 1999.

SANDRP: Explained: Seti River floods in May 2012, Nepal- A chain of events, starting at 25,000 feet!, [online] Available (Accessed 18 March 2021), 2014.

Schild, A.: ICIMOD ’s Position on Climate Change and Mountain Systems, , 28(3), 328-331, 2008.

Schwanghart, W., Bernhardt, A., Stolle, A., Hoelzmann, P., Adhikari, B. R., Andermann, C., Tofelde, S., Merchel, S., Rugel, G., Fort, M. and Korup, O.: Repeated catastrophic valley infill following medieval earthquakes in the Nepal Himalaya, Science (80-. )., 351(6269), 147-150, doi:10.1126/science.aac9865, 2016.

Schwanghart, W., Ryan, M. and Korup, O.: Topographic and Seismic Constraints on the Vulnerability of Himalayan Hydropower, Geophys. Res. Lett., 45(17), 8985-8992, doi:10.1029/2018GL079173, 2018.

Sidle, R. C. and Ziegler, A. D.: The dilemma of mountain roads, Nat. Geosci., 5(7), 437-438, doi:10.1038/ngeo1512, 2012. Somos-Valenzuela, M. A., McKinney, D. C., Byers, A. C., Rounce, D. R., Portocarrero, C. and Lamsal, D.: Assessing downstream flood impacts due to a potential GLOF from Imja Lake in Nepal, Hydrol. Earth Syst. Sci. Discuss., 11(11), 1301913053, doi:10.5194/hessd-11-13019-2014, 2014.

Stolle, A.: Catastrophic Sediment Pulses in the Pokhara Valley, Nepal, University of Potsdam., 2018. 
Stolle, A., Bernhardt, A., Schwanghart, W., Hoelzmann, P., Adhikari, B. R., Fort, M. and Korup, O.: Catastrophic valley fills record large Himalayan earthquakes, Pokhara, Nepal, Quat. Sci. Rev., 177, 88-103, 2017.

515 Stolle, A., Schwanghart, W., Andermann, C., Bernhardt, A., Fort, M., Jansen, J. D., Wittmann, H., Merchel, S., Rugel, G., Adhikari, B. R. and Korup, O.: Protracted river response to medieval earthquakes, Earth Surf. Process. Landforms, 44(1), 331341, doi:10.1002/esp.4517, 2019.

Talchabhadel, R., Karki, R., Thapa, B. R., Maharjan, M. and Parajuli, B.: Spatio-temporal variability of extreme precipitation in Nepal, Int. J. Climatol., 38(11), 4296-4313, doi:10.1002/joc.5669, 2018.

520 Thapa, B., Watanabe, T. and Regmi, D.: Flood Assessment and Identification of Emergency Evacuation Routes in Seti River Basin, Nepal, Land, 11(1), 82, doi:10.3390/land11010082, 2022.

UN Office for the Coordination of Humanitarian Affairs - Field Information Services Section (OCHA FISS): Nepal Subnational Administrative Boundaries, Humanit. Data Exch. [online] Available from: https://data.humdata.org/dataset/administrative-bounadries-of-nepal (Accessed 5 January 2022), 2020.

525 United Nations Department of Economic and Social Affairs: World Population Prospect 2019, World Popul. Prospect. [online] Available from: https://population.un.org/wpp/ (Accessed 13 January 2022), 2019.

Wang, W., Gao, Y., Iribarren Anacona, P., Lei, Y., Xiang, Y., Zhang, G., Li, S. and Lu, A.: Integrated hazard assessment of Cirenmaco glacial lake in Zhangzangbo valley, Central Himalayas, Geomorphology, 306(November), 292-305, doi:10.1016/j.geomorph.2015.08.013, 2018.

530 Westoby, M. J., Glasser, N. F., Brasington, J., Hambrey, M. J., Quincey, D. J. and Reynolds, J. M.: Modelling outburst floods from moraine-dammed glacial lakes, Earth-Science Rev., 134, 137-159, doi:10.1016/j.earscirev.2014.03.009, 2014.

Wohl, E. E.: Uncertainty in Flood Estimates Associated with Roughness Coefficient, J. Hydraul. Eng., 124(2), 219-223, doi:10.1061/(asce)0733-9429(1998)124:2(219), 1998.

Zhang, X. and Liu, S.: A framework of numerical simulation on moraine-dammed glacial lake outburst floods, J. Arid Land, 535 7(6), 728-740, doi:10.1007/s40333-015-0133-x, 2015. 